\title{
EQUAL PAY FOR WORK OF EQUAL VALUE IN ONTARIO AND GREAT BRITAIN: A COMPARISON'
}

\section{ELLEN E. HODGSON}

\begin{abstract}
Hodgson's article is a thorough discesssion of the concept of Pay Ecuity. She hegins by providing a proper definition of the term Pay Equity and then goes on of explore the relevam legislation and case law regarding the matter. In order io analyze Pay. Eaquity fully. Hodssom compares the Ontario experience with that of Great Britain. The central comcern of the paper is not to debate the appropriateness of Pay Equity legistation hut. rather. wo determine wherher the courts have responded io the legistation in such a manner as on be able of describe it as being a success. Within her work. Hodyson exposes the reality that Pay liguity legislation in both jurisadictions is complex and costly: however. despite this. the wage gap berween the scixes is diminishing.
\end{abstract}

L'article de Hodgsson office une discussion approfondie du principe de'quiti salariale. Elle commence par le définir. puis érudic les mesures législatives pertinemes a le droit jurisprudentiel dans le domaine. Pour effectuler une analyse complite. Hodgson sompare lespeirience ontarienne er celle de la Grande-Bre'agne. Sa présocoupanion majeure ne est pas de debatrere du bien-fimele de la législation a cer égard mais phuôt de délerminer si le's décisions des mihumanx témoignemt de son stuccès. Hodgsom comstate que les tois sur lérguitio salariale dans les deur juridictions est complexe et coutteuse: les écarts de salaires entre hommes a femmess somt toutefois en voie de diminuer.

\section{TABLE OF CONTENTS}

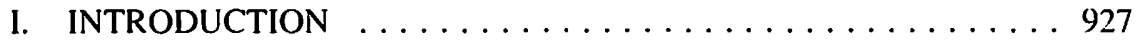

II. ONTARIO PAY EQUITY ACT, $1987 \ldots \ldots \ldots \ldots \ldots \ldots \ldots . \ldots 30$

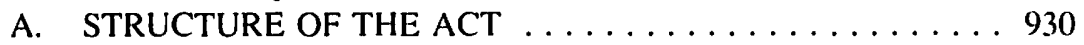

B. PAY EQUITY AMENDMENTS - BILL $168 \ldots \ldots \ldots \ldots 936$

C. ANALYSIS OF SIGNIFICANT PAY EQUITY

TRIBUNAL DECISIONS . . . . . . . . . . . . . . 939

D. CRITICISMS OF THE PAY EQUITY ACT AND

RECOMMENDATIONS FOR AMENDMENT . . . . . . 956

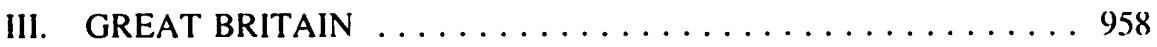

A. DOMESTIC AND EUROPEAN COMMUNITY

LEGISLATION GOVERNING EQUAL VALUE

CLAIMS IN GREAT BRITAIN ............ 958

Excerpts trom this article were presented in a paper at a joint conference in Bellast sponsored by the British Association for Canadian Studies/Associattion for Canadian Studies in Ireland in April. 1992. In addition. excerpts Irom this article were presented in a paper at a seminar in Ldinburgh sponsored by the Centre of Canadian Studies in May, 1992. I wish to thank Dr. Roben Lane of the Europa Institute at the University of Edinburgh for his helpful comments on an carlicr draft of this article. I would like to thank Lillian Macpherson and Caron Rollins of the Weir Memorial Law Library for their generous assistance, and the Oftice of Human Rights at the University of Alberta for the use of their materials. As well. thatnks to Commissioner Brigid O'Reilly and Juclith Killoran of the Pay Equity Commission: Helen Veitch of the Equal Opportunities Commission: and Gary Bowker of Equal Opportunities Review for providing me with informattion. Finally, I am gratteful to Peter $M$. Owen. Q.C., Dean Timothy Christian. Dr. L.arry Pratt and Bernard W. Crotly for their encouragement. Member of the Alberta Bar. Currently enrolled in Master of Laws (LL.M.) degree program at the University of Edinburgh. 


\section{B. EQUAL VALUE CLAIMS FOLLOWING THE EQUAL PAY (AMENDMENT) REGULATIONS $1983 \ldots \ldots$. . . . . . 962 \\ C. CASE LAW ON EQUAL VALUE CLAIMS . . . . . . . . . 968 \\ D. CRITICISMS OF BRITISH EQUAL VALUE LEGISLATION} AND SUGGESTED AMENDMENTS $\ldots \ldots \ldots \ldots \ldots \ldots 92$

IV. COMPARISON OF PAY EQUITY LEGISLATION IN ONTARIO TO EQUAL VALUE LEGISLATION IN GREAT BRITAIN . . . . . 983

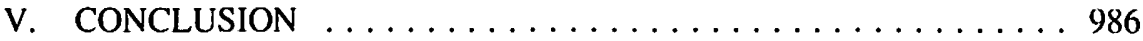

\section{INTRODUCTION}

This article compares the legislation governing equal pay for work of equal value in the Province of Ontario ${ }^{2}$ to that in Great Britain. ${ }^{3}$ While many people in these jurisdictions understand that the law requires men and women doing identical work to receive identical pay, ${ }^{4}$ it is less well understood that the law also requires equal pay for work of equal value, free of sex discrimination.

In both Great Britain ${ }^{5}$ and Ontario, a large gap in earnings between men and women has persisted despite equal pay for equal work legislation." Not all of the male/female wage gap is due to gender discrimination, since other factors such as different training; longer working hours; seniority; additional education; greater productivity; different bargaining strengths of unions; different performance levels; and different labour markets are also factors in determining compensation. Great disagreement exists regarding what portion of the carnings gap between men and women is due to gender discrimination. ${ }^{7}$

Pay. Equity Acr. 1987. S.O. 1987. c. 34.

In Great Britain. equal value claims are govemed by Article 119 of the EEC Treaty. EC Council Directive 75/117 (OJ 1975 L.45/19) (the Equal Pay Directive). the Equal Pay Act (U.K.), 1970). c. 41 and the Equal Pay (Amendment) Regulations 1983, S1 1985/1794. Both Cannadal and the United Kingdom have ratilied a 1951 ILO Convention which requires equal pay for work of equal value. Sce: ILO Connemion (No. 100) Comcerning Equal Remumeration for Men and Women Workers of Equal Value, 29) June 1951, 165 U.N.T.S. 303. The signatories are cited in J.B. Marie, "International Instruments Relating to Human Rights" (1991) 12:1-2 HRLJ 27 at 39.

4. Legislation requiring equal pay for equal (identical) work exists in every Province in Canada, as well as in Great Britain. See: J. Kelly, Pan Eatuity Mamagement (Don Mills: CCH. 1988) at iii regarding equal pay for equal work legislation in Canada: and the Echal Pay A.t (U.K.). 1970). c. 4l. s. 1(2) for Great Britain.

5. "Great Britain" means England. Scolland and Wales due to the provisions of the Union With Sionland Act (England), 1706, c. 11. preamble, art. I ISee: Halshurg's Shames, Vol. 17, 4th ed., title European Communities ill 30] and the Uniom With England Act (Scolland), 1707. c. 7 [See: The Laws of Scotheml. Stair Memorial Encyclopedia. Vol. 22 (Edinburgh: The Law Society of Scotland/Butterworths, 1987) at 55]. The "United Kingdom" means Great Britain and Northern Ireland: Interpretution ACt (U.K.). 1978. c. 30, s. 5. Sch.1. Throughout this article, a distinction is maintained between legislative provisions and statistics pertaining to Great Britain and those pertaining to the United Kingdom.

" See Hon. R. Abellit, Eanulity in Employment: A Roval Commission Repont (Ottawa: Minister of Supply and Services Canada. 1984) at 233-5 regarding the persistent nature of the gap in Cantada.

J. Gandz, "Pay Equity: Negotiating the Maze" in D. Conklin \& P. Bergman. eds. Pay Equity in Ontario: A Manager's Guide (Halifax: Institute for Research on Public Policy. 1990) 81 at 82-83. See also C. O’Donnell and N. Golder, "A Comparative Analysis of Equal Pay in the United States. 
Some authors take the position that it is possible that discrimination affects "... each and every component of the overall wage gap. For example, differences in hours worked may reflect an inequitable division of labour within the household...."

In any case, whatever portion of the earnings gap is due to systemic discrimination against women, such a gap exists both in Ontario and in Great Britain. The gap, however, does appear to be narrowing gradually over time. In Ontario, the female to male earnings ratio has increased from $63.6 \%$ in 1979 to $67.4 \%$ in $1989 .{ }^{9}$ These figures are similar to those for Canada as a whole which experienced an increase from $63.5 \%$ in 1979 to $65.8 \%$ in 1989." Statistics Canada stated in a 1989 report that the "...long-term trend in the female/male earnings ratio is clearly upward." 1

In Great Britain, the gap is also narrowing, but the extent of the increase varies depending on whether gross hourly earnings excluding overtime, or gross weekly earnings including overtime are considered. At the time that the Equal Pay Act was passed in 1970 , women's earnings were approximately $63.1 \%$ of men's in Britain, based on average gross hourly earnings for full-time employees. The figure had increased to $73.0 \%$ in $1979^{12}$ and to $76.0 \%$ in $1989 .^{13}$ In 1991 , women's earnings were $77.8 \%$ of men's earnings, showing that the gender earnings gap is slowly decreasing. ${ }^{14}$ The gap appears wider when gross weekly earnings are considered: women's earnings as a percentage of men's have increased from $63.6 \%$ in $1979^{15}$ to $67.6 \%$ in $1989 . .^{16}$ Viewed this way, the gender wage gap in Ontario and Great Britain in 1979 and 1989 was virtually identical.

The Equal Opportunities Commission attributes the wider differentials in the British weekly earnings figures to the fact that men have longer basic hours and greater access than women do to overtime, shift premia and bonus payments. ${ }^{17}$

The Pay Equity Act, 1987 is unique in Canada in that although other jurisdictions have pay equity legislation, ${ }^{18}$ the Province of Ontario initiated the requirement that employers

Britain and Australia (1986) 3 Australian Fem. S. 59 at 59-60.

Ontario, Minister Responsible for Women's Issues, Green Paper on Pay Equity (Toronto: Queen's Printer, 1985). (The Hon. I. Scont, Minister Responsible for Women's Issues) at 11 [hereinafter Green Paper on Pay Equity].

Statistics Canada, Earnings of Men and Women 1989 (Ottawa: Minister of Supply and Services Canada, 1990) at 10.

Ibid.

Ihid. al 12.

Equal Opportunities Commission, Women and Men in Britain: A Research Proffle (London: HMSO, 1988) at 45-47.

"Women earn $\mathrm{fl} 100$ per week less than men" (1991) 40 E.O.R. 28.

Supra, note 13 at 28.

Supra, note 12.

Supra, note 13.

Equal Opportunities Commission, Women and Men in Britain 1989 (London: HMSO, 1989) at 24. Pay equity legislation requiring equal pay for work of equal value exists in the public sector in the Federal jurisdiction, Québec, the Yukon, Ontario, Manitoba, Nova Scotia, Prince Edward Island, and New Brunswick. In the North West Territories, a complaint under the Canadian Human Rights Act results in a pay equity study. Newfoundland is experimenting with a non-legislated pay equity 
be required to prepare pay equity plans to achieve and maintain pay equity in both the public and the private sectors. ${ }^{19}$ In essence, this means that disparate jobs are evaluated in terms of factors such as skill, responsibility, effort, and working conditions. Comparisons are made between diverse jobs to determine whether the work is of equal value to the employer. ${ }^{20}$

In Ontario, the assumption is made in equal pay for equal value legislation that there is systemic discrimination against women in job valuation and pay determination. In its Green Paper on Pay Equity, the Government of Ontario stated that pay equity is directed at the portion of the gender gap which is due to gender discrimination in job evaluation and pay determination. It stated that pay equity is not addressed to remedying low wages but, rather, to the concept that "... excluding non gender-related factors which influence pay, work performed by women which is equivalent to that performed by men in the same establishment is to be paid the same."21

Simply put, "pay equity means compensating female jobs at the same level as male jobs of equal or comparable value."22 This necessarily means looking at different jobs, evaluating their worth, and changing traditional pay structures.

In contrast, the legislation in Great Britain is not limited to women, but makes provision for equal pay for equal work, including equal value claims, for men and women free of sex discrimination. ${ }^{.33}$

In Great Britain, the Equal Pay Act, 1970 made provision for equal pay for equal work, or "like work" claims. This statute also provided for "equivalent work" claims. Different legislative provisions apply in Northern Ireland. ${ }^{24}$ Upon joining the European community in 1973, the United Kingdom became obliged to enact various provisions to comply with the EEC Treaty. ${ }^{25}$ The EEC passed Directive $75 / 117$ in 1975 , and

initiative. The legislation in Ontario, Qućbec and the Federal jurisdiction extends to the private sector. The Canadian Human Rights Act extends pay equity to federally regulated industries in the private sector. See: J. Kelly, Pay Equity Managemem (Don Mills: CCH, 1988) at iv-v; N. Weiner and M. Gunderson, Pay Equity, Issues, Options and Experiences (Toronto: Butterworths, 1990) at 107-129: M.L. Burkart, Implementing Pay. Equity in Ontario. School of Industrial Relations Research Essay Series No, 28 (Kingston: Industrial Relations Centre, 1990) at 1-17 for explanations of the differing requirements of the legislation in these jurisdictions. Ontario. Ministry of Labour. Policy Directions: Amending the Pay Equity Act Discussion Paper (Toronto: Queen's Printer, 1990) at 2.

Ibidl. at 4.

Supra, note 8 at 3 .

N. Weiner \& M. Gunderson, Pay Equity: Issues. Options and Experiences (Toronto: Butterworths, 1990) at 5.

Equal Opportunities Commission. Equal Pay for Men and Women: Strengthening the Acts (Manchester: Equal Opportunities Commission. 1990) at 1.

The Equal Pay Act (U.K.). 1970. c. 41, s. II(3) provides that the Act does not apply to Northern Ireland. Accordingly. it only pertains to Great Britain.

Treaty Establishing the European Economic Community, 25 March 1957, No. 4300, 298 U.N.T.S. 3 [hereinafter the EEC Treaty). This treaty pertains to the United Kingdom. There are two other European Community treaties. namely the Treaty Establishing the European Coal and Steel Community, 18 April 1951, reprinted in Treaties Establishing the European Communities 
thereafter the United Kingdom was obliged to enact legislative measures providing equal pay for equal work, including equal value claims without discrimination based on sex..$^{26}$ Amendments to the Equal Pay Act, 1970 enabling British workers to make equal value claims came into effect in 1984. ${ }^{27}$

Unlike the Ontario legislation, the British legislation is complaint-based and depends upon individuals making claims. Comparisons in equal value claims in Great Britain are made on the basis of individuals, not groups of male and female employees, as the woman chooses a male comparator to whose work she thinks her work is comparable. ${ }^{28}$ Any increases in compensation are limited to the claimant, as no mechanism exists for workers in the same employment who perform similar work to receive the same award. ${ }^{29}$

There are endless arguments to be made for and against legislation requiring equal pay for work of equal value, free of sex discrimination. Since the decision has been taken in both Great Britain and Ontario to enact legislation giving effect to this principle, this paper will not attempt to evaluate whether such legislation is appropriate or desirable. ${ }^{30}$ Instead, the focus will be on examining the nature of the legislation which has been enacted in these jurisdictions and on suggestions as to how to improve their effectiveness at achieving their stated goals.

\section{ONTARIO PAY EQUITY ACT, 1987}

\section{A. STRUCTURE OF THE ACT}

The scheme of the Pay Equity Act, 1987 attempts to rectify the portion of the wage gap between men and women in the work force that is attributable to systemic gender discrimination. This type of discrimination is embedded in compensation systems and does not refer to intentional discrimination by individuals. ${ }^{31}$ It is hoped that the Act will

(Luxembourg: Oflice lor Official Publications of the European Communities, 1987) at 23 and the Treaty Establishing the European Atomic Energy Community. 25 March 1957, 298 U.N.T.S. 167. Since we are concerned exclusively with the law of the European Economic Community, the term "Community law" will be used to mean the law of the EEC.

26. Supra, note 23.

27. Equal Pay (Amendment) Regulations 1983, SI 1983/1794 reg. I. These regulations do not extend to Northern Ireland. The Equal Pay (Amendment) Regulations (Northern Ireland) 1984 apply in that jurisdiction.

2*. Equal Pay Acr (U.K.). 1970, c. 41. s. 1(2)(c).

39. Supra, note 23 at 2 and 25.

in. For a discussion favouring equal value or pay equity legislation, see: R.P. Chaykowski, Pay Equity Legislation: Linking Economic Issues and Policy Concerns. Research and Current Issues Series No. 59 (Kingston: Industrial Relations Center, 1990) at 10-19. For a discussion opposing the concept of equal value legislation, see: E.F. Paul, Equity and Gender: The Comparable Worth Dehate (New Brunswick: Transaction Publishers, 1989) at 39-61. There are dozens of other publications dealing with the philosophical and economic aspects of this type of legislation. A good discussion of both sides of the issue is found in J. Kelly, Pay Equity Management (Don Mills: $\mathrm{CCH}, 1988$ ) at 7-23.

3. The Pay Equity Commission. Report to the Minister of Lahour by the Ontario Pay Equity Commission on Options Relating to the Achievement of Pay Equity in Sectors of the Economy which are Predominantly Female (Toronto: The Pay Equity Commission, 1989) (Commissioner: B. $O^{\prime}$ Reilly) at $\mathbf{I}$. 
"...eliminate the one-quarter to one-third of the wage gap which has been created by gender discrimination in wage setting." ${ }^{.32}$ Under the existing Act, a gender neutral comparison of the value of female job classes and male job classes is carried out within an establishment. This is known as a job to job comparison. If the male job class receives greater compensation than an equally or comparably rated female job class, then a pay equity adjustment must be given to the female job class to bring it up to the job rate of the comparable male job class. ${ }^{33}$

\title{
1. Coverage
}

The Pay Equity Act sets out the scheme for implementing an integrated system of achicving pay equity in both the public sector and private sector with 10 or more employees in Ontario. ${ }^{34}$ The Act applies to full-time, and permanent part-time work, but excludes casual work and students employed for their vacation period. ${ }^{35}$

\section{Purpose of the Act}

The purpose of the Pay Equity Act is to "...redress systemic gender discrimination in compensation for work performed by employees in female job classes.. ${ }^{36}$ The mechanism to identify systemic gender discrimination in compensation is by comparing the compensation and value of the work performed by each female job class in an establishment and the male job classes in the establishment. ${ }^{37}$

\section{Job Classes}

The term "job class" is defined as

\begin{abstract}
...those positions in an establishment that have similar duties and responsibilities and require similar qualifications, are filled by similar recruiting procedures and have the same compensation schedule, salary grade or range of salary rates. ${ }^{3 \times}$
\end{abstract}

An "establishment" is defined geographically and includes all of the employees of a particular employer in a geographic division. ${ }^{34}$

Before the comparisons may be made, it is necessary to determine whether a job class is female or male. This is determined according to gender predominance. A female job

B. O'Reilly, Commissioner, "Pay Equity: The View from the Commission" in D. Conklin \& P. Bergman, eds.. Pay Equiny in Omario: A Manager's Guide (Halifax: Institute for Research on Public Policy, 1990) 15 at 15. Ontario, Ministry of Labour, Extending Pay Equity by Proportional Value and Proxy Comparisons (Toronto: Queen's Printer, 1991) at 1.

Pay Equity Act. 1987. S.O. 1987, c. 34, ss. I and 3.

Ibid. at ss. $1(1)$ and $8(3)$.

Ibid. at s. $4(1)$.

Ibid. at s. 4(2).

Ibid. at s. 1(1).

Ihid. 
class is one where at least $60 \%$ of the members are female, and a male job class is one in which at least $70 \%$ of the members are male. ${ }^{40}$

In determining whether a job class is male or female, the Act provides that the "historical incumbency of the job class" and "gender stereotypes of fields of work" are to be considered. ${ }^{+1}$ This means that consideration is to be given as to whether the work performed has traditionally been considered "women's work" and whether the positions have generally been occupied by females. Generally a job class will consist of more than one position; however, it is possible for one position to form a job class if it is unique to the establishment in terms of duties, responsibilities, qualifications, compensation schedules, or recruiting procedures. ${ }^{42}$ The Act requires that in determining the value of work, the criterion applied must be a composite of the skill, effort and responsibility normally required to perform the work, and conditions under which it is normally performed. ${ }^{43}$

\section{Gender Neutral Comparison System}

Once the value of the job class is determined, employers are required to use a "genderneutral comparison system" to compare the female job classes in the establishment with the male job classes in the same establishment to ascertain whether pay equity exists for each female job class. ${ }^{44}$ The term "gender-neutral comparison system" is not defined in the statute. The statute does define, however, when pay equity has been achieved, although the definition is rather complicated. Pay equity is reached once the job rate for the female job class which is the subject of the comparison at least equals the job rate for a male job class at the same establishment where the work performed by the classes compared is of equal or comparable value. ${ }^{\text {t5 }}$ This is called the "inside" comparison. ${ }^{46}$ The "job rate" is the highest rate of compensation for a job class; ${ }^{47}$ "compensation" being defined to include both payments and benefits. ${ }^{48}$

If more than one comparator of equal or comparable value is found, the one with the lowest job rate is the comparator. ${ }^{49}$ This is controversial, as many critics question whether pay equity is actually achieved by paying the female job class the lowest job rate

Ihid. They may also be determined to be female or male job classes if a Review Officer, or the Hearings Tribunal, or the employer and the bargaining agent, if any, so determine the class. See s. 1(1) of the Act.

Pay Equity Act, 1987, S.O. 1987, c. 34, s. I(5).

Ibid. at s. 1(6).

Ibid. at s. 5 .

Ihid. at s. 12.

Pay Equity Act, 1987. S.O. 1987, c. 34. s. 6.

D. Conklin \& P. Bergman, eds., Pay Equity in Ontario: A Manager's Guide (Halifax: Institute for Research on Public Policy, 1990) App. at 101.

Pay Equity Act, 1987, S.O. 1987. c. 34, s. 1(1).

Ibid.

Supra, note 46. 
when the work performed is of equal or comparable value. ${ }^{50}$ Things become complex if there is no male job class of equal or comparable value in the same pay equity plan. In this case, an "outside" comparison is made by looking for one from among other male job classes. If more than one is located, the male job class with the lowest rate is the appropriate comparator. ${ }^{51}$

Finally, if there is no male job class of equal or comparable value to the female job class in the establishment, a job class must be found in the establishment which has work of lower value, but is of a higher job rate, and pay equity is achieved once the female job class is paid the same job rate. This is called a "throughout" comparison. If there is more than one, the one with the highest rate is the appropriate comparator. ${ }^{52}$ Of course, the entire system is predicated on there being male job classes with which to make comparisons. If there are no male job classes, then the female job classes are not able to avail themselves of any remedial compensation increases under the Act. ${ }^{53}$

Where the workplace is unionised, s. 6(4) of the Act requires comparisons for job classes inside a bargaining unit to be made between job classes in that unit. If no male job class of equal or comparable value covered by the same pay equity plan is found, then a search for a comparator in male job classes throughout the establishment is permitted. ${ }^{54}$ Job classes outside the bargaining unit are compared to other job classes inside the unit first; only if no male job class of equal value is found, is the search for a comparator throughout the establishment conducted..$^{55}$

Provision is also made to combine job classes under the group of jobs approach. A "group of jobs" is a series of job classes which are organized in successive levels and have a relationship to each other due to the nature of the work required to perform the work of each job class in the series. ${ }^{56}$ An employer is allowed to treat a group of job classes as one female job class if $60 \%$ of the employees in the group are female. ${ }^{57}$ The significance of the group of jobs approach is that where it is used, s. 6(9) provides that the job rate of the individual job class within the group of jobs which has the greatest number of employees is the job rate for the group, and the value of the work performed by that job class is treated as the value of the work performed by the group. In other words, it is not the compensation of a particular group which is the deciding factor in the

See, for example. P. McDermott. "Pay Equity in Ontario: A Critical Legal Analysis" (1990) 28:2 Osgoode Hall L.J. at 392-3. Professor McDermott argues that the method used in Manitoba when more than one comparator is available, which is called an average pay line approach, would be a more appropriate standard.

s. Sipra. note 46.

s. Ihid.

53. Pay Equity Act, 1987, S.O. 1987, c. 34, s. 33(2)(e). This is discussed in O'Reilly, supra. note 32 at 18.

3. "Pay Equity in Ontario" (1991) 40 EOR 22 at 24.

5s. Pay Equity Act, 1987. S.O. 1987. c. 34. s. 6(4)-6(5).

s. Ihid. at s. $6(10)$.

57. The job classes in a group of jobs may also be treated as one female job class if the employer and the bargaining agent so agree, or if the Pay Equity Commission or the Review Officer so order. Pay. Equity Act, 1987, S.O. 1987, c. 34, ss. 6(6)-6(8). The group of jobs may include male job classes: supra, note $46 \mathrm{App}$. at 96. 
group of jobs approach but, rather, it is individual job class which has the most employees which determines the job rate and the value of the work performed by the entire group of jobs. ${ }^{58}$

\section{Obligation to Achieve and Maintain Pay Equity}

The Pay Equity Act in s. 7 places the onus on the employer to establish and maintain a compensation practice providing for pay equity in every one of its establishments. The Act forbids employers and bargaining agents from bargaining for or agreeing to compensation practices that contravene this obligation to achieve pay equity. ${ }^{59}$

There are, however, some permissible exceptions to pay equity, namely a formal gender neutral seniority system: a gender neutral merit compensation plan which has been brought to the attention of the employees; red-circling; temporary training leading to career advancement which is equally available to male and female employees; and skills shortages causing temporary inflation in compensation. ${ }^{60}$

The Act forbids reducing compensation of an employee or of a position in order to achieve pay equity. ${ }^{61}$ Once pay equity has been achieved in an establishment, however, differences in compensation between a female job class and a male job class are permissible if the employer can prove that the difference is the result of differences in bargaining strength.'?

The Act sets out a timetable for the posting of pay equity plans, and for the achievement of pay equity which is based on the number of employees, and on whether the public or private sector is involved. Public sector employers must achieve pay equity by 1995. All other employers with 10 or more employees must implement pay equity over a six year period that has been phased in according to the size of the employer. ${ }^{63}$

\section{Pay Equity Plans}

The Act requires documents called pay equity plans to be prepared to provide for pay equity for the female job classes in each establishment. The number of plans required is determined by factors such as who the employer is, the number of bargaining units, the number of employees, and the number of establishments. ${ }^{\text {it }}$ If both male and female job classes exist, cvery pay equity plan for the establishment must describe the gender neutral comparison system selected, set out the results of the comparisons, identify positions and job classes which have permissible differences in compensation, and must describe how

sx. Supra, note 50 at $398-401$.

54. Pay Exurity Act, 1987. S.O. 1987, c. 34. s. 7.

(4) Ihid. at s. 8 . Red circling refers to the practise of freezing or slowing down increases in compensation of an incumbent when a position has been downgraded, until the compensation of the position reaches that of the incumbent: supra. note 46 App. at 104.

1. Pay. Equity Ac\%, 1987, S.0. 1987. c. 34. s. 9.

1.2 $\quad$ bid. al s. $8(2)$.

a. Ibid. at s. 13(7). A chart is provided in supra, note 46 at 120-1.

at Supra. nole 54 at 22. 
compensation will be adjusted commencing on a particular date with respect to all female job classes for which pay equity does not exist. ${ }^{65}$

Where there is a bargaining unit, pay equity plans are negotiated and agreed to by the employer and the bargaining agent. A separate pay equity plan is created for each bargaining unit unless agreement is reached that the establishment includes two or more geographic divisions. A separate pay equity plan is required for the employees who are not in a bargaining unit. ${ }^{\text {so }}$ Two or more employers and the respective bargaining agents may agree that the employees constitute a single establishment for the purposes of pay equity. ${ }^{67}$ If there is no union, the pay equity plans are not negotiated but are established by the employer and must be posted by the relevant posting date. if any. ${ }^{6.8}$

The Act does not give much guidance as to how increases in compensation are to be shared in order to achieve pay equity. ${ }^{69}$ Employers are required to pay a minimum of the lesser of the amount required to achieve pay equity; or $1 \%$ of their payroll, based on the payroll for the 12 months prior to the first adjustments. in combined compensation payable under all pay equity plans of the employer. ${ }^{70}$ Each pay equity plan must provide that the female job class or classes with the lowest job rate receive compensation increases greater than those for other female job classes under the plan until their job rate equals the lesser of the job rate required to achieve pay equity, or the job rate of the female job class entitled to an adjustment which has the next lowest job rate. ${ }^{71}$

In the private sector where pay equity plans have been prepared and posted, these payments are to continue until pay equity is achieved. Small private sector employers with between 10 and 99 employees are not required to post pay equity plans but may decide to do so. ${ }^{72}$ If they elect not to post plans, they are not required to commence making compensation changes in stages to achieve pay equity but, nonetheless, must have achieved pay equity by the relevant mandatory adjustment date. ${ }^{73}$ The public sector is required to achicve pay equity by 1995 .

\section{Administration and Enforcement}

The Act provides for administration and enforcement through the Pay Equity Commission and its Review Officers. The Commission is the body with whom

\footnotetext{
os Pạ Equiny A1\% 1987. S.O. 1987. c. 34. s. 13.

thid. al s. 13(.3).

w. Ibid. at s. 2.

ax. Ihid. al s. 15. See B.J. Falk. "A Reasoned Response: Pay Equity in Ontario" in R. Chaykowski. ed.. Pay Equity Legislation: Linking Foconomic Issues and Policy Concerns (Kingston: Industrial Relations Centre. 1990) 10 at 13.

D. Conklin. "How to Cope with Pay Equity I.cgislation" in D. Conklin \& P. Bergman. cds.. supra. nole 46 at $7-8$.

Pay Equisy. Act. 1987, S.O. 1987, c. 34, s. 13(4).

Ihid. at s. 13(3).

Ibid. al s. 20.

Ibid. at s. 21. This is explained in supra. note 46 App. at 113-15.
} 
complaints are filed with respect to alleged contraventions of the Act. ${ }^{74}$ It consists of the Pay Equity Hearings Tribunal and the Pay Equity Offices. ${ }^{75}$ Review officers for the Commission investigate complaints and try to effect a settlement. Review Officers have the power to make orders requiring employers and bargaining agents to prepare plans and employers to implement plans. They have the ability to refer matters to the Hearings Tribunal if the employer or bargaining agent fails to comply with an order under s. 24 of the Act. ${ }^{76}$

The Pay Equity Tribunal has exclusive jurisdiction to determine questions of fact or law arising before it. It is protected by a strong privative clause. ${ }^{77}$

\section{B. PAY EQUITY AMENDMENTS - BILL 168}

1. Pay Equity Commission Recommendations Regarding Options Relating to Achieving pay Equity in Predominantly Female Sectors

At the time the Pay Equity Act was passed, it was recognized that the benefit of the Act would not extend to women in workplaces which lack male comparators. Section 33(2)(e) of the Act required the Pay Equity office to conduct a study regarding systemic gender discrimination for work performed in predominantly female sectors of the economy and regarding female job classes in establishments with no appropriate male job classes for comparison.

The Pay Equity Commission submitted a report to the Minister of Labour in January 1989 which identified five options and set criteria against which they could be measured, and recommended further study. ${ }^{78}$ The Commission then submitted a further report on options to achieve pay equity in predominantly female sectors in October, 1989. ${ }^{79}$ The report notes that occupational segregation exists which is coupled with "traditional undervaluing of women's work." ${ }^{* 10}$ In predominantly female sectors, nearly all the jobs are performed by women. In Ontario, eleven sectors of the economy are predominantly female. In the public sector, this includes childcare, health care, community and social services, public libraries and educational services. In the private sector this includes apparel and clothing manufacturers, manufacturing, financial and insurance, personal and business services, tourism and retail. ${ }^{\mathrm{g}}$

Pay Equity Act, 1987, S.O. 1987, c. 34, s. 22.

Ihid. at s. 27.

Ihid. at ss. 23-24.

Ihid. at s. 30.

The Pay Equity Commission, Report to the Minister of Labour by the Pay Equity Commission of Ontario on Sectors of the Economy which are Predominantly Female as Required by the Pay Equiny Act, 1987 Section 33(2)(e) (Toronto: The Pay Equity Commission, 1989) (Commissioner: G. Podrebarac).

Siupra, note 31 .

Ibid. at I.

Ibid. at 6 . 
In this report, the Commission recommended that the Pay Equity Act be amended to add an additional step to the process so that a pay equity adjustment may be calculated for female job classes that lack a male comparator under the process in the current Act. ${ }^{\mathrm{X}}$

The Commission recommended that various additional methods of comparing job classes be added to the Act, including proportional value; internal average adjustment; and proxy comparisons for the public sector. ${ }^{83}$ Pay-outs to achieve pay equity using the new methods of comparison should be completed in the public sector by $1995 .^{8.4}$ Amendments to the Employment Standards Act to increase the minimum wage and to extend greater protection to casual and part time workers were suggested. ${ }^{\mathrm{xs}}$ The Commission also recommended that the level of government funding to the public sector be increased to address under-valuation of women's work in that sector and the "overall low wage problem." ${ }^{\text {"6 }}$

\section{Bill 168: An Act to Amend the Pay Equity Act}

The work of the Pay Equity Commission evidently was well received, since most of its suggestions have been incorporated in Bill 168, An Act to Amend the Pay Equity Act ${ }^{87}$ introduced on December 18, 1991. The amendments to the Act are highly innovative, rather radical and are sure to be controversial. The government introduced the bill despite the poor economic climate and spending restraints. The NDP government is obviously committed to extending the benefits of the Act to women who are currently unable to take advantage of its benefits, as is shown by the following comments of Premier Bob Rae: "I think it's important to send a clear signal that even in the toughest of circumstances we're not going to forget the social-justice agenda." ${ }^{\text {"X8 }}$

Bill 168 introduces additional methods of comparison, namely the proportional value comparison method ${ }^{89}$ and proxy comparisons. The Minister of Labour estimates that the amendments will extend coverage of the Act to an additional 420,000 women. ${ }^{* 0}$

In order to understand how innovative these amendments are, an explanation is required of what the terms "proportional value method of comparison" and "proxy method of comparison" mean. Proportional value comparisons are a method of indirectly comparing male and female job classes by examining the relationship between the compensation received and the value of the work performed by male job classes and applying the same

x2. Ihid, at 109.

x. Ihid. at 116-17.

s. $\quad$ Ibid. at 118.

s. Ihid. at 120 .

x6. Ibid. at 123.

Bill 168. An Act to Amend the Pay. Equity Act, Ist Sess., 35th Leg. Ont., 1991 [hereinafter Bill 168].

"Restraints Won't Affect Pay Equity. Rae Says" The [Toronto] Globe and Mail (17 January 1992) AS.

x4. The proportional value comparison method is currently used in Manitoba. New Brunswick and Prince Edward Island. See: supra, note 31 at 41.

9). Ontario, Legislative Assembly, Official Report of Dehates (Hansard), No. 101, 1991 at 4400 (18 December 1991). 
principles to compensating female job classes. There are several variations to this type of comparison, but each permits a relative comparison to be made for all female job classes to the male job classes in an establishment, despite there being only a few male job classes available for the comparisons."

Bill 168 provides that the proportional value method of comparison is to be used if a female job class cannot be compared to a male job class in the establishment using the job-to-job method found in the current Act. If this method of comparison is used in a situation where the job-to-job method of comparison is also appropriate, the compensation adjustment made for members of that female job class may not be less than the adjustment indicated under the job-to-job method. ${ }^{92}$

The proxy method of comparison is also to be used in the public sector in the event that neither the job-to-job method or the proportional value method of comparison is suitable. The bill provides that systemic gender discrimination in compensation is to be identified by comparing the compensation and value of the work performed between each female job class in the employer's establishment and job classes in an establishment of the proxy employer. ${ }^{93}$ Under this method, female job classes are compared to male job classes in an outside public sector establishment, called the proxy Organisation. The pay equity adjustments given to the female job classes in the "seeking" organisation are based on the rates found in the pay equity plan of the proxy organisation. ${ }^{94}$ The seeking organisation may ask the proxy organisation for its job descriptions, as well as the male and female job rates in the pay equity plan and use them in their organisation. ${ }^{95}$

At the time the Bill received first reading, the government stated that the introduction of amendments permitting proportional value and proxy comparisons permitting women to find male comparators will resolve the need for litigation seeking to have the government declared the employer in order to achieve pay equity. ${ }^{96}$ It was noted that various pay equity and public service Labour Relations Tribunal decisions had determined

Ontario Ministry of Labour, Policy Directions: Amending the Pay Equity Act Discussion Paper (Toronto: Queen`s Printer. 1990) at II.

12. Supra, note 87 at cl.11. The Bill does not specify which proportional value method is to be used. Briefly. the choices include firstly giving female job classes which did not find male comparators, adjustments proportional to those received by female job classes which did find comparators. The second approach. known as the formula approach. involves expressing the value of male and female job classes in points, and calculating the average dollar value of each point for male job classes, in order to ascertain the relationship between the point value and the wages. The equitable salary for each female job class is found by multiplying the dollars per point by the point assigned to each female job class. Finally, the wage line approach involves drawing a wage line showing the relationship between the value of the male job classes and the compensation they receive. The female job classes are compared to the male wage line to determine whether the female job classes are "... paid fairly based on their value to the organisation." Supra, note 31 at 41-45.

9.3. Supra, note 87 all cl.12.

21. Ontario Ministry of Labour. Extending Pay Equity by Proportional Value and Proxy Comparisons (Toronto: Queen's Printer. 1991) at 2-3. See also Ministry of Labour, Release. "Background," (December 1991) at 4.

\%. Supra, note 31 at 54-68 and 111 for an explanation of the proxy comparison approach.

*. Supra, note 90 at 4401 . 
that a larger organisation such as the province is the employer for pay equity purposes, and this created the potential for many public sector employees to become Ontario public service workers. The stated objective of the changes is to enhance the government's ability to manage the size of its work force. ${ }^{37}$ This was the impetus for its announcement of imminent amendments to the Pay Equity Act, ${ }^{\text {"N }}$ the Public Service Act and the Crown Employees Bargaining Act. ${ }^{99}$

In order to demonstrably support the extension of the proxy method of comparison to the public sector, the NDP Government announced a commitment to provide funding "... based on a commitment to pay $100 \%$ of the cost of proxy for non-profit broader public sector employers." (10)

The Bill will strengthen the powers of Review Officers investigating complaints so that they will be able to issue corrective orders with regard to additional matters ${ }^{101}$ such as requiring the employer to amend a pay equity plan which is no longer appropriate and issuing orders that employers, employees and bargaining agents comply with the Act. ${ }^{102}$ The Tribunal will be able to require employers, employees and bargaining agents to comply with written settlements that the parties have reached with respect to a matter in respect of which the Tribunal is required to hold a hearing. ${ }^{103}$ The Act will be amended so that in the event that a company is sold, transferred or restructured, the purchaser will acquire the existing pay equity plan. ${ }^{104}$

Finally, the private sector will be affected by a new administrative measure requiring employers to post signs explaining workers' rights under the Act and telling them where they can seek advice if they feel these rights are not being respected. ${ }^{105}$

\section{ANALYSIS OF SIGNIFICANT PAY EQUITY TRIBUNAL DECISIONS}

Although there are over 200 decisions interpreting the Pay Equity Act, 1987, the case law is still in its infancy. The Pay Equity Tribunal has yet to develop the law regarding the application of the Act to the private sector. Since a legal aid clinic whose mandate includes assisting unorganized women in bringing complaints under the Act officially opened in December, 1991, there will doubtless be cases pertaining to the private sector

Ibid. at 4401 .

Clause 2 of Bill 168 provides that the Crown is only a person's employer in the event that person is a civil servant, public servant or Crown employee under the Public Service Act.

Supra, note 90 at 4401.

Ibid. at 4406.

Ihid. at $\mathbf{4 4 0 0}$.

Bill 168, All Act to Amend the Pay Equity Act. 1st sess.. 35th Leg. Ont., 1991, cl. 14.

Ihid. at cl. 16.

Supra, note 90 at 4400 .

Ihid. at $\mathbf{4 4 0 0}$. 
in the near future. ${ }^{106}$ The clinic provides free representation and legal advice for female employees or unions with small resources. As well, once the January 1,1993 and January 1, 1994 deadlines to achieve pay equity pass for small private sector employers who choose not to post pay equity plans, it is likely that cases will arise.

The cases in respect to the public sector have dealt with issues such as the jurisdiction of the tribunal to consider the Charter $;{ }^{107}$ the division of pay equity plans along gender lines; ${ }^{108}$ the powers of Review officers; ${ }^{109}$ penalising employees for exercising their rights under the Act; ${ }^{110}$ and whether Tribunal decisions are hearings de novo. ${ }^{11}$

116. The Pay Equity Advocacy \& Legal Services Clinic (PEALS) opened in December, 1991. The Ministry of Labour will provide $\$ 500,000$ in funding for each of the clinic's first two years of operation. Prior to that, an interim counselling service operated out of Parkdale Community Legal Services as a pay equity project from May, 1991 to November. 1991. PEALS is part of the legal aid system. See: Ontario Ministry of Labour. News Release, "Labour Minister opens Ontario's First Pay Equity Clinic" (12 December 1991) and PEALS. Pay Equity Advocacy \& Legal Services brochure. The Pay Equity Tribunal has recently determined that it has jurisdiction to hear Charter arguments with respect to matters raised before it on the basis of s. 52 of the Constitution Act, 1982 and the Tribunal's exclusive jurisdiction to exercise powers conferred on it in s. $\mathbf{3 0}$ of the Pay Equity Act: Parkwood Hospital (1991) 2 P.E.R. 178 at Para. 12-14 (P.E.H.T.) [hereinafter Parkwood Hospital]. The main issues in this case have not been determined, which are whether s. 6 of the Pay Equity Act prevents seeking a male comparator job class which is paid more but valued less when there is no equal or comparable male comparator, and the fact that s. 6(3) requires that when more than one male comparator of equal or comparable value exists, the one with the lowest job rate becomes the comparator. The O.N.A has submitted that determining the appropriate comparator involves consideration of whether s. 6 of the Act offends s. 7 and 15 of the Canadian Charter of Rights and Freedoms, Part I of the Constitution Act, 1982, being Schedule B of the Canada Act, 1982 (U.K.), 1982 (c. 11). The latest development in this case was the Tribunal's decision that the O.N.A. has standing to raise the Charter argument. See Parkwood Hospital at para. 3-6.

The 1990 Tribunal decision in Wentworth County Board of Education, (1990) 1 P.E.R. 132 (P.E.H.T.) considered numerous issues, including the division of pay equity plans along gender lines, the appropriate number of pay equity plans, the number of job classes, the criteria to be permitted to intervene as a party, and the definition of "position." In this case, a Review Officer had ordered preparation of separate pay equity plans for male and female teachers, among other requirements. The Tribunal held that dual male and female pay equity plans would defeat the purpose of the Act by creating a female pay equity plan with job classes mirroring those in the male plan, thus eliminating any possible pay adjustments for teachers (at 152).

Various sections of the Act deal with the powers of Review Officers to investigate complaints, make orders, and effect settlements. Re Carlton Cards (1991) 2 P.E.R. 91 (P.E.H.T.) deals with referrals to the Tribunal by Review Officers. As well, the decision in O.N.A. v. St. Michael's Hospital (No. 1) (1991) 2 (P.E.R.) 182 (P.E.H.T.) considered the question of the Tribunal's jurisdiction where the Review Officer has not notified the parties or the Tribunal pursuant to s. 23(2) that a settlement cannot be effected. The ability of parties to circumvent the settlement process with a Review Officer and proceed directly to the Tribunal was an issue in Thunder Bay Family and Children's Services (1990), 2 P.E.R. 27 (P.E.H.T.). See 2:20 F.C.E.E.R. at 157 for a summary. Finally the decision in New Liskeard Board of Police Commissioners (No. I) (1990), 2 P.E.R. 39 (P.E.H.T.) determined that Review Officers lack the power to provide a remedy for contraventions of s. 9(2) of the Act (at 4), and set out the procedure for parties wishing to pursue allegations that the Section has been breached (at 10).

110. See for example New Liskeard Board of Police Commissioners (No. I) (1990), 2 P.E.R. 39 (P.E.H.T.) wherein the Association lodged a complaint pursuant to s. 9(2) of the Act, and the majority of the Tribunal held that the Association had failed to establish the allegation that the Board of Police Commissioners had penalised a clerk for exercising rights under the Act. 
1. Cases Regarding Who is the "Employer"

(a) Haldimand-Norfolk (No. 3)

The case law in this area is fairly extensive, although inconsistent due to various applications of the tests to determine who is the employer which were set out in Haldimand-Norfolk (No. 3)."12 This line of cases is significant because the Tribunal's interpretation of who is the employer in various cases became enough of a concern to the Ontario Government that it introduced Bill 168 in the Legislative Assembly partially as a response to the expanded definition of employer.

The Pay Equity Act does not define the term "employer", and accordingly it was left up to the Tribunal to develop a suitable definition. In a series of cases, the Ontario Nurses Association (O.N.A.) alleged that the Regional Municipality of Haldimand-Norfolk (the "Regional Municipality") had acted contrary to the Act. In Haldimand-Norfolk (No. $3)$, the Tribunal considered whether or not the Regional Police Force should be included in the "establishment" of the Regional Municipality for pay equity purposes. ${ }^{113}$

The O.N.A. argued for a broad definition of employer in order that a larger establishment, namely the Regional Municipality, would be used for pay equity purposes. In this way, it could be argued at the stage of collective bargaining that the police could be used as a comparator for nurses. The Board of commissioners of police (the "Board") argued that it was an employer in its own right and argued for adoption of the Ontario Labour Relations Board case law definition of "employer." Counsel for the Municipality also submitted that this definition of "employer" should be adopted. ${ }^{1 / 4}$

The Tribunal decided that the Act contains both an anti-discrimination component and a labour relations component, whose purpose is to provide "relief and redress to women for wage discrimination." 115 The Tribunal rejected the argument that in the absence of a statutory definition of "employer" in the Act, that it was bound by the definition found in the Ontario Labour Relations Act, ${ }^{116}$ since its purpose is to regulate labour relations rather than to redress gender wage discrimination. ${ }^{17}$ The panel found that the approach used by the Labour Board was helpful in that it indicates that a flexible approach is appropriate and no single indicium is determinative of who is the employer. ${ }^{118}$

See O.P.S.E.U. v. Cybermedix Health Services (1989), I P.E.R. 4 I (P.E.H.T.); and Wentworth County Board of Education (1990), 2 P.E.R. 37 (P.E.H.T.); and Police Assn, New Liskeard) v. New Liskeard Police Commissioners (1990), 35 C.C.E.L. 159 (P.E.H.T.).

112. Haldimand-Norfolk Regional Board of Commissioners of Police et al. v. Ontario Nurses Association et al. (No. 3) (1989), I P.E.R. 17 (P.E.H.T.), (1989) 30 C.C.E.L. 139 (Ont. S.C.), aff,d (1990) 41 O.A.C. 148 (Ont. C.A.) |hereinafter Haldimand-Norfolk (No. 3) cited to P.E.R.|.

Ihid. at 33.

Labour Relations Act, R.S.O. 1980, c. 228.

Supra, note 112 at 34.

11x. Ihid. at 34. 
The Tribunal set out four criteria to be applied when determining who is the employer, which it stated were not intended to be all encompassing:

\section{WHO HAS OVERALL FINANCIAL RESPONSIBILITY?}

Indicia of this test include: Who has responsibility for the budget? Who bears the financial burden of compensation practices, and the burden of wage adjustments under the Act? Who is responsible for the financial administration of the budget? What is the shareholder investment or ownership? Who bears the responsibility of looking after the deficit or benefiting from the surplus?

\section{WHO HAS RESPONSIBILITY FOR COMPENSATION PRACTICES?}

The indicia for this criteria include: Who sets the overall policy compensation practices? Who attaches the value of the job to its skill, effort, responsibility and working conditions? What is the labour relations reality? Who negotiates the wages and benefits with the union or sets the wage rate in a non-unionised setting?

3. WHAT IS THE NATURE OF THE BUSINESS, THE SERVICE OR THE ENTERPRISE?

Within this test the following are helpful indicia: What is the core activity of the business, service or enterprise? Is the work in dispute integral to the organization or is it severable or dispensable? Who decides what labour is to be undertaken and attaches that responsibility to a particular job? What are the employees' perceptions of who is the employer?

\section{WHAT IS MOST CONSISTENT WITH ACHIEVING THE PURPOSE OF (SIC) PAY EQUITY ACT?}

If there is more than one possible employer, it assists the Tribunal in its determination to make reference to the purpose and objectives of the Pay Equity Act, 1987.119

With respect to the fourth criterion, the Tribunal stated that s. 4 provides that the purpose of the Act "... is to redress systemic gender discrimination in compensation for work performed by employees in female job classes." ${ }^{20}$ The Tribunal then applied the four tests and found on balance that the Regional Municipality was the employer and that the police force is part of the "establishment" of the Regional Municipality for pay equity purposes. ${ }^{121}$

Dissenting Tribunal member Sharon Laing accepted the four criteria, but dissented on the findings that the Regional Municipality was the employer and that the police force was part of the establishment of the Regional Municipality for pay equity purposes. ${ }^{122}$

On appeal, the Ontario Supreme Court decided in view of the strong privative clause in s. 30(1) of the Act that the appropriate standard of review was whether the legislator 
intended the question to be within the jurisdiction conferred on the Tribunal. As well, the court held that the question of who is the employer is one that the legislator intended the Tribunal to determine. As the Tribunal's decision was not patently unreasonable, the application by the Regional Municipality was dismissed. ${ }^{123}$ This was later upheld by the Ontario Court of Appeal. ${ }^{124}$

The decision has been criticized on the basis that the four criteria it establishes could result in lifting the corporate veil for purposes of implementing the Act. The decision could arguably affect private sector corporations operating a number of different businesses in the same geographic region, or those participating in joint ventures. ${ }^{125}$

\section{(b) Middlesex and London}

The four Haldimand-Norfolk (No. 3) criteria to determine who is the employer were applied in Middlesex and London ${ }^{126}$ but with very different results. In this case, the O.N.A. applied to have the County of Middlesex and the corporation of the City of London declared the employer of the nurses at the Board of Health Middlesex-London Health Unit for purposes of pay equity. The City, the Health unit, and the county all argued conversely that the Health unit was the employer.

The Tribunal was of the view that a definition of employer should be arrived at which is appropriate to furthering the objectives of the Act and which recognises the realities under which the parties must carry out their obligations under the Statute. Since the focus of the Act is on control over compensation practices, it is helpful to identify the party which bears the burden of remuneration. ${ }^{127}$ The Tribunal then followed the approach of Haldimand-Norfolk ( $\mathrm{No}, 3$ ) and applied the four criteria of that case to determine who was the employer. ${ }^{12 \mathrm{x}}$

With respect to the first criterion, who has overall financial responsibility, the Tribunal stated that the notion "responsibility for the budget" is not simply who gives ultimate budgetary approval, or who provides funding, particularly in the public sector where government funding is relied on by agencies: "Rather, this notion includes factors such as who is responsible for establishing the budget and is ultimately accountable for its administration." 29

Secondly, regarding who bears responsibility for compensation practices, the Tribunal held that the Health Unit hired staff and agreed to compensation depending on the skills, effort and working conditions of the staff's jobs. ${ }^{131}$

Haldimand-Norfolk (No. 3) (1989), 30 C.C.E.L. 139 (Ont. S.C.) at 144-6.

Haldimand-Norfolk (No. 3) (1990), 41 O.A.C. 148 (Ont. C.A.).

R.D. Dale, "The Pay Equity Act: Who is the Employer?" in D. Conklin \& P. Bergman, eds., supra, note 46 at 29.

Middlesex and London (1989), I P.E.R. 89 (P.E.H.T.) (hereinatiter Middlese.x and London).

Ibid. at 103.

Ibid. at 101-103.

lhid. at 106.

Ihid. at 108. 
In applying the third criterion, namely the nature of the business, service, or enterprise, the Tribunal distinguished the facts of the case from those in Haldimand-Norfolk (No.3) in that in Middlesex and London there was no clearly enunciated statutory obligation for the Municipality to provide public health services. The Health Unit's main activity was provision of public health programmes in a manner which was relatively independent of the Municipality.

Finally, with regard to the fourth criterion, the Tribunal stated that it would be inappropriate to determine that the City or County were the employer simply to provide the O.N.A.'s members with male comparators with which to compare female job classes at the Health Unit: ${ }^{131}$

... Where the evidence points inescapably to the conclusion that one party is the employer, it would be inappropriate to make a finding inconsistent with the evidence simply on the basis that to do otherwise would deprive female job classes of male comparators in a particular workplace. ${ }^{132}$

Thus, unlike Haldimand-Norfolk (No. 3), a narrow view was taken in this case of who was the employer. The Tribunal held that the employer was the Health Unit, since the Board of Health was responsible for establishing its budget, subject to provincial approval; was responsible for financial administration of the budget; and was responsible for compensation practices and for evaluation of the work performed by the nurses. As well, the Board of Health negotiated collective agreements and bore the burden of wage adjustments. It was responsible for delivery of public health programmes; determining which work would be done; and for attaching responsibility to the positions. ${ }^{133}$ The Tribunal arrived at this conclusion although $90 \%$ of the Health Unit's total budget was provided by the province, ${ }^{134}$ and despite the fact that the Province reviewed the Health Unit's budgets on a line-by-line basis.

\section{(c) Metropolitan Toronto Library Board}

Another significant decision developing the Haldimand-Norfolk (No. 3) fourth criterion is Metropolitan Toronto Library Board. ${ }^{135}$ In this case, the issue was whether the Metropolitan Toronto Library Board or the Municipality of Metropolitan Toronto (Metro) was the employer of the Metropolitan Toronto Library staff. ${ }^{136}$ C.U.P.E. argued that the library staff's employer for pay equity purposes was Metro and that the staff should be included in the establishment of Metro. This was significant as the determination of what was the establishment determined which positions were available as comparators for female job classes. ${ }^{137}$

\footnotetext{
131. Ihid. at 110-111.

132. Ibid. at 111.

133. Ibid. at 111 .

13. Ihid. at 107.

13s. Metropolitan Toronto and Metropolitan Toronto Library Board (1989), I P.E.R. 112 (P.E.H.T.) (hereinafter Metropolitan Toromto Library Board).

13. Ibid. at 112 .

1.37. Ibid. at 114 .
} 
The Tribunal noted the definition of "employer" in various statutes and jurisprudence and stated that the meaning of the term should be taken from the purpose and context of the statute. The Tribunal noted that the Supreme Court of Canada accepted the Abella Report ${ }^{1.38}$ on equality in employment approach to systemic discrimination in Canadian National Railway Company v. Canadian Human Rights Commission, ${ }^{139}$ wherein the Court stated that it is essential to create a climate in which negative practices and attitudes are discouraged in order to combat systemic discrimination. ${ }^{1+1}$

If the Pay Equity Tribunal rejected the argument that the employer for pay equity purposes is the employer named in the collective agreement, since the focus of the Act is compensation rather than control over hiring and firing. ${ }^{141}$ The parties named in the collective agreement will be considered by the Tribunal but are not determinative.

The Tribunal considered the four criteria from Haldimand-Norfolk (No. 3) and stated that although Tribunal panels are not bound by decisions of other panels, that consistency in decisions would provide certainty and direction, promote settlement, and discourage multiplicity of proceedings. ${ }^{142}$ The Tribunal stated that the fourth criterion in Haldimand-Norfolk (No. 3) is meant to be used to evaluate which of the other three criteria are most indicative of the employer/employee relationship:

...If the application of the first three criteria clearly point to an entity as the employer, resort to the fourth criterion may not be necessary. It will be used then, to reconcile or balance the first three criteria if their application leads to different entities as possible employers in a particular fact situation. ${ }^{143}$

The Tribunal held based on the application of the first three Haldimand-Norfolk (No. 3) criteria to the facts that Metro was the employer for pay equity purposes. This was because Metro had overall responsibility for the Library Board's budget and the extent of the review of the library's programmes and services was such that Metro was not simply the source of funds. With regard to responsibility for compensation practices, it held that Metro most heavily influences and thus is responsible for these practices. Thirdly, with regard to the nature of the service, the library provided a service for Metro which was not severable from the Metro Corporation. ${ }^{144}$

\section{(d) Barrie Public Library Board}

Another line of cases has adopted a radically different interpretation of the HaldimandNorfolk (No. 3) criteria. This includes Barrie Public Library Board, ${ }^{145}$ and the

Supra, note 6.

Canadian National Railway Company v. Canadian Human Rights Commission (1987), 87 C.L.L.C 16255 at 17,022 (S.C.C.).

Supra, note 135 at 116.

lhid. at 117-118.

Ibid. at 120.

Ibid. at 120.

Ihid. at 130-31.

Barrie Public Library Board (1991), 2 P.E.R. 93 (P.E.H.T.), (22 October 1991) 0048-90, 0059-90, 0067-90 (P.E.H.T.) [hereinafter Barrie cited to P.E.R.]. 
Porcupine Health Unit decisions. ${ }^{146}$ In Barrie, the main issue was who was the employer of the staff at the Barrie Public Library. The close relationship between the City and the Library Board was noted, including the fact that staff at the Library sit on City's committees; the city's Director of Personnel has been the spokesperson on the Library Board's negotiating committee; and the City performed a payroll function for the Library without charge. ${ }^{147}$

The majority decision states that there is no definition of "employer" in the Act; however, there are indications in ss. 8(2) and 9(2) that it was intended that the term be interpreted in a manner which recognises existing relationships between employers and employees, and between employers and bargaining agents. For example, s. 8(2) which permits differences in remuneration between male and female job classes once pay equity is achieved where the difference is the result of differences in bargaining strength, "... contemplates a congruence between the entity that bargains wages with employees, either collectively or individually, and the entity with obligations under the Act."148

The Tribunal noted that the establishment and maintenance of pay equity will alter the workplace and may change existing hierarchies. In its view, the enquiry should commence with identifying the parties to existing collective bargaining and employment relationships. The lack of the definition of "employer" indicates that the Tribunal may need to go beyond existing structures to define "employer." Particularly in the non-union sector where it has never been necessary for the parties to determine who is the employer, it may be difficult to identify the parties to the existing relationship.

The Tribunal then departed completely from Haldimand-Norfolk (No. 3) by stating that the focus of the Act is on reviewing compensation practices and valuing work, thus the Tribunal's enquiry "... should centre on identifying the entity that is responsible for existing compensation practices and the valuing of work." 149 There are few cases in which there will be a party other than the one responsible for employment obligations, although there may be instances where the named employer in the collective agreement is not the entity which attaches value to the work and sets compensation policy. ${ }^{150}$

The majority of the Tribunal reviewed the four Haldimand-Norfolk (No. 3) criteria and held that the second test, that of "...what is the labour relations reality, who negotiates the wages and benefits with the union or who sets the wage rate in the non-unionised setting?" is paramount. ${ }^{151}$ The majority stated that "In the vast majority of cases, the

Porcupine Health Unit (No. I) (1991), 2 P.E.R. 78 (P.E.H.T.) (12 December 1991) 0014-89 (P.E.H.T.). In the December, 1991 majority decision, the change in focus in Barrie was adopted. The panels in both cases were chaired by the same Vice-Chair. As in Barrie, the parties did not request reconsideration of the criteria, rather, the issue was put forward by the Tribunal. In this case, both the majority and minority agreed that the Health Unit was the employer and that the outcome would not be changed by applying the original Haldimand-Norfolk (No. 3) criteria. 
existing collective bargaining or employment relationships will be the ones used for the implementation of pay equity...."152 The first two tests in Haldimand-Norfolk are useful in assessing which entity is responsible for valuing work and for compensation practices. The first test may indicate which entity has indirect control over these matters while the second test looks more at direct control. ${ }^{153}$

The Tribunal departed from existing jurisprudence by stating that the part of the third criterion which refers to determining whether the activity is a "core" activity or is integral to the organization is not helpful in the public sector, because there are always links between different levels of government and agencies such as the Library Board. Although the decision to deliver such services via an agency rather than a government department does not make the service less integral to the government, it does reflect a choice to provide them via agencies that are autonomous from government to an extent: "Evidence relating to that autonomy is relevant to the Tribunal since it assists in determining who controls compensation policy and who attaches value to the work performed." ${ }^{154}$ The Tribunal stated that the part of the third criterion that asks who determines what work is to be undertaken and attaches responsibility to a particular job was useful as an indication of which entity is responsible for valuing work. ${ }^{155}$

The majority stated that identifying whether the activity is core to the organization may be more helpful in the private sector. This part of the third criterion should only be used when it is unclear from the first two tests which entity controls compensation practices and the valuation of work. ${ }^{156}$

Finally, the majority adopted the comments from Middlesex and London that where the evidence points inescapably to one party as the employer, it is inappropriate to make a finding inconsistent with the evidence simply because otherwise female job classes would be deprived of male comparators. The fourth criterion will only be used where the evidence on the first three criteria leave doubt regarding which entity is the employer and should not be used in the initial weighing of evidence. ${ }^{157}$ Accordingly, the majority held that the first two tests from Haldimand-Norfolk (No. 3) and the first part of the third test will elicit evidence in most cases upon which a determination can be made as to who is the employer for pay equity purposes.

Applying these guidelines to the facts of this case, the majority held that the Library Board was the employer. The Board controlled its compensation practices and valued work performed. Thus, the responsibility to address any gender discrimination in compensation should also be its responsibility. ${ }^{158}$

$\begin{array}{ll}\text { 15. } & \text { Ihid. at } 6 . \\ \text { 1s3. } & \text { Ihid. at } 7 . \\ \text { 1.s. } & \text { Ihid. at } 7 . \\ \text { 15s. } & \text { Ihid. } \\ \text { 1.5. } & \text { Ihid. } \\ \text { 157. } & \text { Ihid. at } 8 . \\ \text { 1.5. } & \text { Ihid. at } 9 .\end{array}$


Tribunal member Bruce Budd dissented on the basis that the facts supported a different outcome and that the change to the Tribunal's established tests would create confusion in the community. In his view, whether the established Haldimand-Norfolk (No. 3) tests were applied, or whether those of the majority in this case were applied, the City was the employer of the library staff. ${ }^{159} \mathrm{Mr}$. Budd listed 13 facts supporting his decision that the City was the employer in this case, the most significant of which was the uninterrupted direct involvement of the City's Personnel Director on the Library Board's negotiation team in all collective bargaining with the Library staff since its inception.

Mr. Budd conceded that the fourth criterion from Haldimand-Norfolk (No. 3) had been developed in Metropolitan Library Board and Middlesex and London. ${ }^{160}$ However, the essential problem with the majority decision is that it will cause confusion since it places more significance on maintaining existing collective bargaining relationships than on achieving the anti-discrimination purpose of the Act. ${ }^{161}$ Obviously, the truncated tests in Barrie will result in fewer male comparators being available, and thus many female job classes may be deprived of the benefit of the Act due to unavailability of an appropriate comparator. Arguably this is not consistent with the aim of the Act.

C.U.P.E. then requested that a plenary session of the Tribunal reconsider the decision in Barrie. This request was denied on the basis that it would be contrary to the provisions of s. 30(1) of the Act to fetter the Tribunal's jurisdiction to determine a question of law by establishing a binding definition of the term "employer."162

\section{Adjusting Compensation for Female Job Classes: Gloucester}

The recent decision in Gloucester ${ }^{163}$ is important because it lays down principles regarding how to adjust the rates of compensation for incumbents in female job classes to achieve pay equity. In this case, C.U.P.E. and the City of Gloucester negotiated a compensation system creating eight numbered salaried levels called "Groups," each of which had six lettered steps. In the usual case, new employees commenced at the start rate within a particular Group and received annual adjustments based on their service and merit. ${ }^{10-1}$ The parties in this case were unable to agree regarding whether each incumbent in the female job class should receive the same dollar adjustment to achieve pay equity with the male job class which was found to be of comparable value; ${ }^{165}$ or if pay equity would be accomplished by moving the range of salary rates for the female job class to the range of rates of the male job class since the job rates would then be identical. ${ }^{160}$

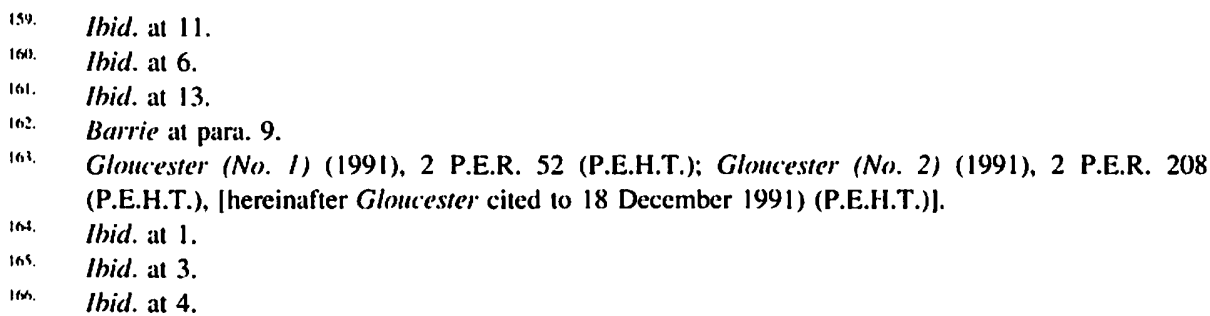


More specifically, the facts were that a female job class which had been placed in Group 11 with a job rate of $\$ 807.09$ bi-weekly was found to be of equal value to a male job class located in Group 13 which had a job rate of $\$ 1,029.69$ bi-weekly. Each job rate was the highest rate of compensation for the job class, the highest "step" within the group. ${ }^{167}$

The City of Gloucester and C.U.P.E. agreed that the job rate for the female job class had to be adjusted upwards by $\$ 222.60$ bi-weekly to at least equal the male job rate in order to achieve pay equity. The parties were unable to agree however, on how the compensation rates should be adjusted for the incumbents in the female job class. ${ }^{168}$

C.U.P.E. submitted that s. 9(3) of the Act was determinative of the issue, as it says that when it is necessary to increase the rate of compensation for a job class, each position in the job class must receive the same dollar adjustment. ${ }^{169}$ Therefore the Union submitted that the adjustment of $\$ 222.60$ bi-weekly should be added to each increment level or step in Group 11. The City argued that each step within Group 11 should move to the same step within Group 13 (i.e. an employee at step C within Group 11 would thus be moved to step C within Group 13). ${ }^{170}$

The Tribunal stated that s. 9(3) of the Act refers to "positions" in a job class, rather than to "incumbents" in a job class. The term "position" is not defined in the Act. However, a "job class" is defined in s. 1(1) to mean those positions which have similar duties and responsibilities; similar qualifications; similar recruiting procedures; and which have the same compensation schedule, salary grade, a range of salary rates. ${ }^{171}$ In order to constitute a job class, positions must meet all of the four criteria: "position, as a subset of job class, must be the same size or smaller than a job class." ${ }^{172}$

The Tribunal then differentiated between the terms "position" and "incumbent," stating that incumbents occupy the same position if they meet all of the four criteria stated above. The majority rejected C.U.P.E.'s submission that each increment level in each range of salary rates is a position and concluded that s. 9(3) did not address the issue in this case. $^{173}$

The majority stated that whatever method of compensation adjustment is selected, it must remedy systemic discrimination in compensation for undervalued female job classes. Accordingly, it was held that each method proposed by the parties in this case was consistent with the Act and would achieve pay equity. However, since the parties could

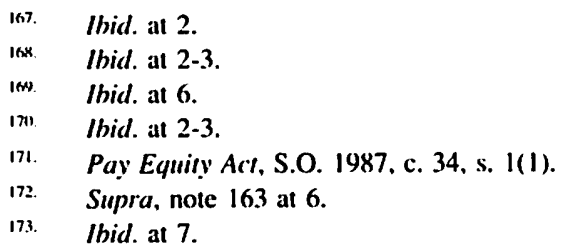


not agree, the pay equity plan was settled by choosing the method proposed by the City. ${ }^{174}$

The majority chose this method of adjusting compensation for four reasons:

First, it moves the range of salary rates for the female job class to the same range of salary rates for the comparable male job class found to be of comparable value.... Second, the incumbents in the female job class will reach the job rate in the same number of steps as the incumbents in the male job class.... Third, this approach will maintain a relationship between the steps in the female job class.... Fourth, the method of adjustment proposed by the city makes good compensation sense. It moves incumbents in a female job class directly into the same steps in the salary range as the incumbents in the comparable male job class. C.U.P.E.'s method would create a "shadow grid" for the adjusted rates which would be different than the grid for the comparable male job class and different than the grid for female job classes which did not receive a pay equity adjustment.... ${ }^{175}$

The dissenting Tribunal member, Gerri Sheedy, disagreed since in her view, s. 9(3) of the Act required that employees in the undervalued class receive the same adjustment in dollar terms. ${ }^{176}$ She noted that C.U.P.E. relied on a literal interpretation of s. 9(3) of the Act to define "position" and observed that this term is not defined in the statute but is used in different ways in various sections. Ms. Sheedy reviewed the Justice Committee hearings in respect of s. 9(3) and concluded that the Section was intended to "... adjust each level within a female job class by the same dollar amount throughout the grid." 177

The minority stated that the repercussion of the majority's holding that s. 9(3) does not address the issue in this case leaves only s. 6 to determine how pay equity is to be achieved. Thus, once the female job rate is made equal to the job rate of the male comparator, nothing further need be considered. Since "job rate" is defined as the highest rate of compensation, only the employees in female job classes at the top rate of compensation would receive an adjustment if the majority's approach is followed. Thus, the employees in the female job class who are not at the top rate would not get any increase or pay equity adjustment. ${ }^{178}$

\section{Gender Neutral Comparison System: Haldimand-Norfolk (No. 6)}

Haldimand-Norfolk (No. 6) is a significant decision dealing with alleged violations of the statutory obligation to endeavour to agree on a gender neutral comparison system and pay equity plan. ${ }^{179}$ In this case, the O.N.A. alleged that the Regional Municipality had 
adopted a gender biased comparison system and failed to negotiate in good faith to agree on a gender neutral comparison system. ${ }^{180}$

The Tribunal noted that this was the first case litigating the issue of gender neutrality. ${ }^{|1|}$ It observed that the Pay Equity Act does not seek to lay blame on parties but provides a framework to redress systemic wage discrimination. In support of the proposition that the motives and intent of parties who discriminate are not central, the Tribunal quoted ${ }^{122}$ the Supreme Court of Canada decision in Robichand v. Canada (Treasury Board):

\begin{abstract}
Since the Act is essentially concerned with the removal of discrimination. as opposed to punishing antisocial behaviour, it follows that the motives or intention of those who discriminate are not central to its concerns. Rather, the Act is directed to redressing socially undesirable conditions quite apart from their reasons for existence. ${ }^{1 \times 3}$
\end{abstract}

The Tribunal noted that s. 12 creates an obligation on the Employer to use a gender neutral comparison system to compare female and male job classes to ascertain whether paly equity exists. The panel held that for a comparison system to be gender neutral, it must be able to analyze and remedy systemic wage discrimination. ${ }^{1 \times 4}$

The Tribunal concluded that there are four elements of a gender neutral comparison system required under s. 13 of the Act:

\begin{abstract}
...the accurate collection of job information: deciding on the mechanism or tool to determine how the value will attach to the job information: applying the mechanism to determine the value of the work performed: and making the comparisons.... Accordingly, the Tribunal finds that parties must negotiate and endeavour to agree upon these elements of a gender neutral comparison system in order to meet the obligations to describe the system as required by section 13 of the Act. ${ }^{1 \mathrm{xs}}$
\end{abstract}

Furthermore, s.5 of the Act requires that the skills, effort, responsibility and working conditions required in the female and job classes which are being compared must be accurately recorded and valued. The Tribunal provided four considerations to be used in evaluating the gender neutrality of the collection of job information part of the comparison system:

-What is the range of work performed in the establishment?

-Does the system make work, particularly women's work, visible in this workplace?

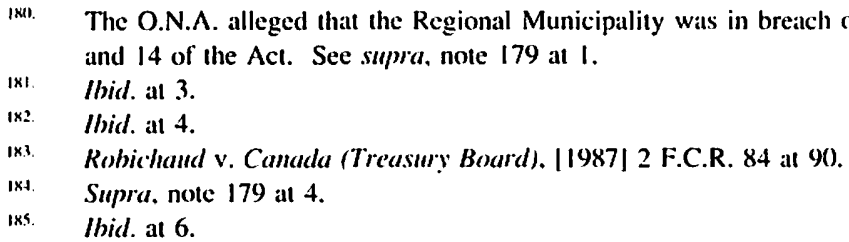


-Does the information being collected accurately capture the skill, effort and responsibility normally required in the performance of the work and the conditions under which it is normally performed for both the female job classes in the plan and the male job classes to be used for comparison?

-Is the job information being collected accurately and consistently, the same way for each job class to be compared? ?kt $^{1 \times 1}$

With regard to the range of work performed in the establishment, the comparison system must consider the particular establishment to which it will be applied having regard to such matters as the type and range of job functions and the nature of the organisation. ${ }^{187}$

The second and third criteria are interrelated. The parties must pay special attention to making visible the aspects of women's work which have been unrecognised in the past:

Given that most women and men perform different jobs, with different skills and job content characteristics, one of the initial and key requirements of a gender neutral comparison system is to make visible those job characteristics, using the statutory criteria, that were previously not visible and thus not valued. The system must account for and reflect the differential job characteristics of both male and female work and positively value them.... A comparison system for pay equity purposes must gather or collect job information to be able to assess the skills, effort, responsibility and working conditions normally required in the performance of the work. The system must capture and value the work that is required, so that the Employer can meet the requirement to pay equitably for it. We are persuaded that to do anything less, would be to perpetuate systemic wage discrimination.... ${ }^{1 \mathrm{x}}$

The Tribunal then gave examples from studies ${ }^{189}$ of the type of job content which it will assess in determining whether a proposed gender neutral comparison system captures the value of work required in female job classes. This includes frequently overlooked job content in female jobs such as fine motor skills; special body coordination; scheduling appointments and coordinating meetings; sitting for long periods of time; communication stress from giving emotional support to distressed or ill people; and responsibility for patients, among others. ${ }^{190}$

The Tribunal also quoted a 28 item list published by the pay Equity Office ${ }^{191}$ which identifies frequently overlooked aspects of women's work including such items as operating and maintaining several different types of office, manufacturing, treatment/diagnosis or monitoring equipment; training and orienting new staff; representing the organisation through communication with clients; and frequent bending or lifting of office or medical supplies, injured or sick people or children, among others. ${ }^{192}$

\footnotetext{
186. Ibid. at 10.

187. Ihid. at 10.

18x. Ibid. at 11 .

1*4. R. Steinberg \& L. Haignere, "Equitisblc Compensation: Methodological Criteria for Comparable Worth" in C. Bose \& G. Spitze, Ingredients for Women's Employment Policy (State University of New York: 1987).

1\%. Supra, note 179 at 11.

141. Pay Equity Commission, Implementing Pay Equity in the Workplace (Toronto).

142. Supra, note 179 at $11-12$.
} 
In addition, the Tribunal stated that there is a requirement to give value to the alternative ways in which women's work is organised in order to make women's work visible. For example, women frequently work in cooperative team structures rather than in managerial hierarchies. ${ }^{193}$ It is noteworthy that the Tribunal stated that statistical evidence was of limited use in testing gender neutrality: "at best, statistics may guide parties on where to look for problems in the system...."194

The Tribunal then went on to establish four criteria to assist parties in selecting a tool or mechanism to determine how to attach value to the information collected using the statutory criteria. As well, the panel assessed the point factor comparison system advocated by the employer in great detail, none of which will be discussed here. The Tribunal also listed questions which had assisted it in assessing the gender neutrality of the evidence with respect to applying the tool to determine the value of the work. This included such questions as whether the valuing tool of the comparison system was applied consistently without regard to the gender of the job class, and in the event that a committee is used to evaluate jobs, was it representative balancing the interest of the parties with duties and obligations under the Act. ${ }^{195}$

With regard to the allegation that the employer had failed to bargain in good faith, the Tribunal observed that the purpose of the Pay Equity Act is to redress systemic discrimination, and that the self-interest of the parties in pay equity negotiations does not take precedence over the statutory requirement to establish and maintain pay equity. The Tribunal listed various indicia to assess whether there had been a failure to meet the statutory obligations in ss. 7 and 14 of the Act, which included such matters as whether the employer had recognised and negotiated with the bargaining agent as defined by the Act and whether sufficient information was provided to enable the other party to intelligently appraise the proposals. ${ }^{196}$

The Tribunal stated that any attempt to deal directly with employees or local union officials instead of with the bargaining agent would violate the Act. ${ }^{197}$ As well, it is a violation of the obligation to negotiate in good faith to refuse to negotiate with one local except upon terms being negotiated with another local. ${ }^{196}$

There is an obligation to negotiate and endeavour to agree upon all the component parts of the pay equity plan and a gender neutral comparison system. ${ }^{199}$ Although each party is entitled to adopt a particular interpretation of the Act's requirements, a party cannot refuse to discuss other interpretations. This is because the Act sets the content, time 
frames, and results to be achieved in examining past wage setting practices and in designing an affirmative action plan to redress wage discrimination. ${ }^{200}$

As well, the Tribunal held that parties are not allowed to opt out of their statutory obligation to negotiate and to try to agree on a gender neutral comparison system and pay equity plan because of cost and efficiency concerns. The time-frames set out in the Act do not justify unilateral decision making by one party. ${ }^{201}$

Applying the criteria to the facts of this case, the Tribunal held that the Regional Municipality had failed to negotiate in good faith and to endeavour to agree to a gender neutral comparison system and pay equity plan. It had failed to recognize the bargaining agent. The comparison system advocated by the employer did not meet the statutory requirement of gender neutrality, and, in particular, it did not accurately capture or value the content of the skill, effort, responsibility and working conditions of the work required to be done by the female job classes. ${ }^{202}$ The Tribunal ordered the Regional

\section{0. \\ Ibid. at 45-46. \\ Ihid. at 47.}

202.

Ihid. at 49. Haldimand-Norfolk (No.6) was reheard by the Pay Equity Hearings Tribunal and a decision rendered on May 19.1992: Haldimand-Norfolk (19 May 1992) 0001-89 (P.E.H.T.). The O.N.A. requested that the Tribunal reconsider the May, 1991 decision and sought extensive remedies for the failure of the Regional Municipality to comply with the Order. The Regional Municipality admitted non-compliance, stating that this was primarily due to financial reasons because it lacked funds necessary to retain consultants to draft a bargaining proposal for a comparison system. As well, it lacked the staff expertise to assess the O.N.A.'s proposed comparison system (at 2). It also relied on the provincial government's refusal to provide further funding to continue the pay equity process. The Regional Municipality stated that it had obtained reimbursement in the amount of $\$ 343,668.00$ from the Provincial Government for the costs of the proceedings towards its costs of $\$ 1,308,452.00$. The Regional Municipality stated that it could no longer afford to hire its own counsel and thus withdrew from the hearing. The issues in this case were whether the Tribunal should reconsider and vary the decision; whether the Tribunal should state a case to the Court under the Statutory Powers Procedures Act. R.S.O. 1990, c. S.21; and whether compensatory damages and legal costs in the nature of a "make whole" order should be awarded.

The Tribunal declined to consider the request to state a case for contempt and declined to award legal costs for the proceedings. It held that the May, 1991 Order was varied and awarded compensatory damages to the O.N.A. in the form of a "make whole" order to try to return it to the position it would have been in but for the breach of the Order. The employer had not complied with the Order to negotiate in good faith to negotiate a gender neutral comparison system and pay equity plan. It held that the O.N.A.'s proposed comparison system was an appropriate system upon which to design a pay equity plan. A Review Officer was ordered to be assigned to prepare a pay equity plan and to conduct a pilot test of the O.N.A. comparison system. The majority of the Tribunal ordered that the Regional Municipality pay the costs of preparation of the pay equity plan. The dissenting Tribunal member was of the view that it would be punitive to require the Regional Municipality to pay for the Review Officer's preparation of the plan and did not think that the officer was compelled to adopt the O.N.A.'s proposed system but agreed with the rest of the Order (at 10). It was sufficient to award compensatory damages to return O.N.A. to the position it would have been in, but for the breach (at 10).

The costs of the parties in terms of consultants' fees, legal fees and time were enormous in this case. It was acknowledged that both parties had incurred "considerable expenses at the outset" (at 13) in hiring job evaluation specialists. Evidently the breach of the Regional Municipality and the impasse between the parties was also a major factor in the enormous legal costs. However, the case raises concerns about the costs to parties in complying with their obligation to negotiate and achieve 
Municipality to negotiate in good faith, and ordered the union and the Regional Municipality to table and negotiate a proposed gender neutral comparison system within sixty days.

\section{Mississauga Hydro Electric Commission}

The Tribunal recently considered the issue of the standing of the Pay Equity Office to enforce Review Officer's Orders in Mississauga Hydro Electric Commission. ${ }^{203}$ In this case, the employer, Mississauga Hydro Electric Commission ("Hydro"), and the International Brotherhood of Electrical Workers Local 636 (the "union") had been unable to resolve a dispute regarding the union's allegations that Hydro had failed to maintain pay equity. Hydro had given pay increases to the Outside Unit, which consisted mainly of male jobs, pursuant to their collective agreement without giving corresponding increases to the female job classes in the Inside unit that had been found comparable to various male job classes in the Outside Unit. The Review Officer had issued an Order requiring Hydro to give the female job classes the negotiated increase. He also made orders regarding retroactive pay adjustments and the identification of male comparators, which were matters that had not been in dispute. Hydro objected to parts of the order and requested a Tribunal hearing. The parties then settled and the Tribunal adjourned the matter. The Review officer then referred the matter to the Tribunal pursuant to s. 24(5) of the Act based on the opinion that the parties were not complying with his Order.

The Union and Hydro were content with their settlement and did not seek to enforce the Order. They contended that the P.E.O. lacked the jurisdiction to question their settlement. The P.E.O. contended that there is a gap in the Pay Equity Act in that if the parties reach a settlement following a Review Officer's Order which does not comply with the order or the Act, there is no means of enforcement. The P.E.O. argued that it needs standing to enforce its Orders in order to carry out its mandate to enforce the Act.

The Tribunal observed that the parties to a Tribunal hearing listed in s. 32(1) do not include the P.E.O. The Tribunal stated that the test for allowing one to be added as a party is whether the person is substantially and directly affected by the outcome in the case. It held that the P.E.O. was not affected by the outcome of the case and denied it status to bring the application. ${ }^{204}$

The Tribunal canvassed other regulatory schemes such as the Employment Standards $A c r^{205}$ and concluded that the enforcement procedures in the Pay Equity Act were such

pay equity, particularly when assistance is sought from the Provincial Government to cover the cost of legal representation. The May, 1991 decision was the result of hearings which lasted 60 days (at 1). Arguably the dissent is correct and it would be appropriate for both parties to share in the costs of the Review Officer preparing the plan. After returning the O.N.A. to its former position, it is punitive for the Employer to bear all the costs of preparation of the plan (at 12).

203. Mississauga Hydro Electric Commission (I June 1992) 0321-92 (P.E.H.T.).

so4. Ibid. at 4.

20.5. Employment Siandards AC', R.S.O. 1990, c. E-14. 
that it could not "... conclude that the Legislature intended the P.E.O. to have standing to enforce its orders in unionized workplaces." 206

Although it is an offence to hinder or obstruct Review Officers in carrying out their duties, ${ }^{207}$ it is not an offence to fail to comply with a Review Officer's Order. The Act does not state that Review Officer's Orders are enforceable by Review Officers or by the P.E.O. Instead, the Act provides a binding mechanism to settle disputes as employers or bargaining agents may seek a hearing before the Tribunal. Tribunal decisions may be filed with the Ontario Court and are then enforceable as decisions of the Ontario Court (General Division). It is an offence to fail to comply with a Tribunal Order.

The Tribunal held that the P.E.O. lacked jurisdiction to review settlements reached during the Tribunal hearing process since the statute does not require P.E.O. approval of settlements. The P.E.O. was denied standing to enforce the Review Officer's Order. Obviously, this decision limits the ability of the P.E.O. to enforce Orders and to ensure that the Act is complied with. However, arguably the decision correctly gives effect to the intention of the Legislature. The Act does not make it an offence to fail to comply with a Review Officer's Order, does not state that settlements require P.E.O. approval, and does not give the P.E.O. the power to enforce orders. ${ }^{208}$

The decision does not mean that the P.E.O. has no ability to be a party before the Tribunal, since the Tribunal stated in obiter dicta that in an instance where the P.E.O. sought the Tribunal's permission to institute a prosecution for offences under s. 26(1), regarding interference with Review Officers carrying out their duties, that, arguably it would have the right to be a party.

\section{CRITICISMS OF THE PAY EQUITY ACT AND RECOMMENDATIONS FOR AMENDMENT}

There are many criticisms which have been made of this Act. Many of them will be addressed by the amendments in Bill 168, in the event that it is passed by the Ontario Legislative Assembly. Proportional value comparisons and proxy comparisons would increase the number of women benefitting from the Act. Of course, extending pay equity by proxy comparisons is a radical move, and the revenues allocated to support this change are bound to be controversial at a time when the economy is perceived to be suffering.

Supra, note 203 at 7.

Pay Equity Act, 1987, S.O. 1987, c. 34, s. 26(1).

Arguably, Bill 168 would not change the outcome of this case. Although cl.19 amends s. 32(1) of the Act so that the parties in a hearing before the Tribunal include "any other persons entitled by law to be parties," the P.E.O. is still not explicitly given standing to enforce a Review Officer's Order. The powers of Review Officers would be strengthened under s. 24(3) by giving them the authority to order employers, employees and bargaining agents to comply with the Act. However, the Bill does not give the P.E.O. authority to review the terms of settlements between the parties. On the contrary, cl.16 permits parties to settle a matter in respect of which the Tribunal is required to hold a hearing and gives the Hearings Tribunal (not the Review Officer) the power to order parties to comply with the written settlement.
} 
However, those who support this type of legislation will be pleased the government is committing funds in order to support the changes proposed.

The Act has been criticised in that it permits various job comparison systems to be used within an establishment. Arguably this allowance for variety creates unnecessary expense and confusion where the systems are incompatible. In Manitoba, the legislation requires agreement on a single comparison system. ${ }^{209}$ Such incompatibility and complexity could become problematic if proportional value comparisons and proxy comparisons are added to the possible types of comparisons used under the Act. As well, as stated earlier, critics oppose the provision in the Act which requires the use of the lowest job rate where there is more than one possible male job class of equal or comparable value. Arguably, instead of the lowest rate, an average pay line approach could have been chosen. ${ }^{210}$

The allowable wage differences are also a source of concern to advocates of pay equity. It is argued that permissible wage differences such as merit compensation systems may be used by employers to avoid their obligations under the legislation. Of particular concern is the allowable wage difference once pay equity has been achieved which is due to different bargaining strengths. ${ }^{211}$

One interest group has recommended the following: the Act be extended to cover private sector workplaces with fewer than ten employees, expand the definition of "establishment" to be a corporate rather than a geographic definition, define employer to include related employers, include all casual workers, and establishment of a fund to cover grants to meet the costs of "paying women fairly."212 Another interest group advocates increasing the minimum wage, requiring employers to file plans and reports and increasing the powers of pay equity officers. ${ }^{213}$

Since there is no requirement on employers to file pay equity plans with the Pay Equity Commission, it is going to be difficult to assess compliance by employers with their obligations under the Act. This will make it difficult to assess the effectiveness of the legislation. ${ }^{214}$

The "group of jobs" provisions, permitting the job class in the group of jobs with the greatest number of employees to be selected as the representative job class seeking a male

Supra, note 50 at $389-91$.

Ihid. at 391-3. See also: R.E. Robb, "The Costs and Benefits of Canadian Pay Equity Policy" in R.P. Chaykowski, ed., Pay Equity Legislation: Linking Economic Issues and Policy Concerns Research and Current Issues Series No. 59 (Kingston: Industrial Relations Center, 1989) 36 at 39. R.E. Robb, supra, note 210 at 39.

National Committee on Pay Equity, Legislating Pay Equity to Raise Women's Wages: A Progress Report on the Implementation of the Ontario, Canada Pay Equity Act (Washington D.C.: National Committec on Pay Equity, 1990) at 90.

NAWL, Achieving Pay Equity in Ontario: The National Association of Women and the Law' Response to Policy Directions: Amending the Pay Equity Act: A Discussion Paper by the Ontario Ministry of Labour (Onawa: NAWL, 1990) at 10-11.

"Pay Equity in Ontario" (1991) 40 E.O.R. 22 at 22. 
comparator, have also been criticized. It is argued that this may eliminate the possibility of a pay adjustment for various job classes in the series which would have received an adjustment if they had been evaluated individually. ${ }^{215}$

Finally, the Act has been criticized because it is extremely expensive to comply with it. Creating a gender neutral performance appraisal system often involves hiring consultants. There is also the opportunity cost when human resource professionals in establishments carry out the comparisons and evaluations, since these steps are complex and time consuming. This becomes even more protracted when negotiations with a bargaining agent are involved. ${ }^{216}$ Of course, there is also the cost of making the pay adjustments to achieve pay equity which we have seen to be the lesser of the amount needed to achieve pay equity for all female job classes or $1 \%$ of the previous year's pay roll.

Despite all the criticisms of the legislation, perhaps it should be noted that the very fact it was passed at all is rather remarkable. The legislation shows a commitment by the Government to the concept of equal pay for equal value, which is backed up by placing the onus on the employer rather than on the individual employee. ${ }^{217}$ Whatever one's philosophical stance is on such legislation, it must be conceded that it is an amazing attempt to remedy perceived gender discrimination in pay.

\section{GREAT BRITAIN}

\section{A. DOMESTIC AND EUROPEAN COMMUNITY LEGISLATION GOVERNING EQUAL VALUE CLAIMS IN GREAT BRITAIN}

British law on equal pay for work of equal value is based on the obligations undertaken by the United Kingdom as a member of the European community. The ability to pursue equal pay claims, including equal value claims, under the Equal Pay Act is not confined to women. Section 1(3) provides that the provisions of the Act framed with reference to women and their treatment relative to men are to be read as applying equally in a converse situation to men and their treatment relative to women. This differs from the Ontario legislation, which is intended to benefit women by addressing the "...undervaluation of female-dominated jobs of equal or comparable value to male-dominated jobs." 218 Benefits under the Pay Equity Act accrue to men if they happen to be in a female job class that receives a pay equity adjustment. ${ }^{219}$

As is the case with the Pay Equity Act in Ontario, the British and European Community lcgislation governing equal pay, including equal value claims, extends to both the public

215. Supra, note 50 at $398-400$.

216. J. Gandz., supra, note 7 at 84-7.

217. Stupra, note 214 at 27.

21x. Pay Equity Commission, Pay Equity Implementation Series No. I (Toronto: The Pay Equity Commission, 1988) at 1:4.

214. Ibid. at 1:5. 
and private sectors. ${ }^{220}$ The purpose of the Equal Pay Act is to secure equal pay without sex discrimination. This is also the objective of the equal pay provisions in Article 119 of the EEC Treaty. ${ }^{221}$ These instruments provide that

If a woman is receiving less pay than a man from the same employer for doing equal work (whether the same or broadly similar work, or different work of equal value) the law presumes that the inequality in pay is due to direct or indirect sex discrimination ...22

Under the Equal Pay Act, male and female employees may claim equal pay without sex discrimination on the basis of like work; equivalent work; or work of equal value. Equal pay claims, including equal value claims, may also be pursued in domestic courts under community law, based on the fundamental right to equal pay in Article 119.

It is important to note that Community law constrains the ability of the United Kingdom to enact legislation in the social sphere. The U.K. could not eliminate the principle of equal pay for work of equal value free of sex discrimination because of its EEC Treaty obligations. Community law is paramount over United Kingdom law. Accordingly, any provisions in United Kingdom law which conflict with Community law must be disapplied. ${ }^{223}$ Unfortunately, the fact that both domestic and Community law is applicable to equal valuc claims makes this area of the law extremely complex.

\section{Equal Pay Act, 1970: "Like Work" and Equivalent Work"}

Great Britain legislated equal pay for equal work in the Equal Pay Act. 1970, but the Act did not come into force until 1975. ${ }^{224}$ The Equal Pay Act. 1970 provides that if the terms of a woman's contract of employment at an establishment in Great Britain do not include an equality clause directly or by reference to a collective agreement, they are deemed to include one. ${ }^{225}$ The Equal Pay Act as it was originally enacted restricted

See the discussion of Case 43/75 Defrenne v. Sociéte Anonyme Belge De Navigation Aérienne (Sabena) [1976] 2 C.M.L.R. 98 (E.C.J.) below, regarding the applicability of Article 119 to the state and private sectors.

221. Equal Opportumities Commission. Equal Pay for Men and Women: Strengthening the Acts (Manchester: EOC, 1990) at 10.

222. Ibid.

23. This is well established in Community case law. The principle was first established in Case $6 / 64$ Costa v. ENEL. $|1964|$ E.C.R. 585. It has been developed in a line of cases including Case $11 / 70$ Internationale Handelsgese'llschaft. |1974| 2 C.M.L.R. 540 (E.C.J.) and Case 106/77 /talian Finance Administration v. Simmenthal, [1978] E.C.R. 629. See Nimz v. Freic und Hansestadt Hamburg (1991). I.R.L.R. 222 at 225 (E.C.J.) wherein the European Court of Justice stated: "It should also be remembered that. according to established case law of the Court (see in particular the judgment of 9 March 1978. Simmenthal, 106/77. rec. p. 629) the national court to whom it falls, under its jurisdiction. to apply the provisions of Community law, is obliged to ensure, the full effect of these measures, disapplying. wherever necessary, on its own authority, any contrary provision of national legislation, without requesting or waiting for the removal of that provision by legislative means or by any other constitutional process." Equal Pay Act (U.K.). 1970), c. 41, s. 9(1). This Act applies to Great Britain but not to Northern Ireland.

lbid. s. 1(1). 
equal pay to cases where individual women could show that they performed "like work" or work which was "rated as equivalent" to that of a male comparator. ${ }^{226}$ Sections $1(2)$ (a) and 1(2)(b) of the Act provide for an equality clause relating to terms of a woman's contract of employment where she is employed on like work and on equivalent work, respectively.

"Like work" was defined in the unamended Act to mean work of a "broadly similar nature" and required that men and women receive the same pay if they perform the same job. When the Equal Pay Act, 1970 came into effect, the second type of claim, that of "equivalent work," required that men and women receive equal pay for work which was rated as equivalent under a job evaluation study. Unfortunately, to make this type of claim, the employer had to accept the job evaluation study as being valid for a claim to succeed under the Act. $^{227}$

\section{Sex Discrimination Act, 1975, Amendments to the Equal Pay Act}

The Equal Pay Act, 1970 was amended by the Sex Discrimination Act, 1975 228 which prohibits discrimination in all aspects of employment and requires equal employment opportunities generally. The two statutes are to be read together so far as possible to produce a harmonious result. ${ }^{229}$ The concept of indirect sex discrimination was introduced into British law by the Sex Discrimination Act, 1975, in s. 1(1)(b). The concept of indirect discrimination in equal pay law refers to an instance where an employer's policy does not differentiate on the forbidden ground of sex, but the policy has the effect of so doing. ${ }^{2.30}$

\section{Article 119 of the EEC Treaty}

When the United Kingdom joined the European Community in 1973, it took on various obligations set out in the EEC Treaty. ${ }^{231}$ Article 119 of the EEC Treaty provides that:

Each Member State shall during the first stage ensure and subsequently maintain the application of the principle that men and women should receive equal pay for equal work.

For the purpose of this Article, 'pay' means the ordinary basic or minimum wage or salary and any other consideration, whether in cash or in kind, which the worker receives, directly or indirectly, in respect of his employment from his employer.

C. O'Donnell \& N. Golder, "A Comparative Analysis of Equal Pay in the United States, Britain and Australia" (1986) Australian Fem. S. 59 at 69.

S.L. Willbum, A Secretary and a Cook: Challenging Women's Wages in the Courts of the United States and Great Britain (Ithaca: Cornell University, 1989) at 16-17.

Sex Discrimination Acr (U.K.), 1975, c. 65, Sch. I.

T.K. Hervey, "Justification for Indirect Sex Discrimination in Employment: European Community and United Kingdom Law Compared" (1991) 40 I.C.L.Q. 807 at 816.

Supra, note 229 at 807 and 816.

Treaty Establishing the European Economic Community, March 25, 1957, No. 4300, 298 U.N.T.S.

3 [hereinafter The EEC Treaty]. 
Equal pay without discrimination based on sex means:

(a) that pay for the same work at piece rates shall be calculated on the basis of the same unit of measurement;

(b) that pay for work at time rates shall be the same for the same job.

Article 119 provided the basis for the United Kingdom's obligation to enact legislation providing for equal pay for equal work. Interestingly, Article 119 was created at French insistence to guard against competitive disadvantage, not for purposes of social justice. The French view was that it was necessary to harmonize social costs of production to ensure that businesses competed on an equal basis throughout the Common Market once barriers to the free movement of persons and capital were eliminated. Over time, Article 119 has become an instrument for the implementation of Community social policy. ${ }^{232}$

\section{The Equal Pay Directive}

Directives are a type of secondary Community law which are addressed to Member States, rather than being of general application. Directives do not create binding legal obligations within Member States as they stand but require Member states to enact legislation to put them into effect by a stipulated date. ${ }^{233}$

The Community clarified the obligations of Member States under Article 119 by enacting Directive 75/117 in 1975..$^{2.4}$ Article 1 of the Equal Pay Directive provides that:

The principle of equal pay for men and women outlined in Article 119 of the Treaty, hereinafter called 'principle of equal pay', means for the same work or for work to which equal value is attributed, the elimination of all discrimination on grounds of sex with regard to all aspects and conditions of remuneration.

In particular, where a job classification system is used for determining pay, it must be based on the same criteria for both men and women and so drawn up as to exclude any discrimination on grounds of $\operatorname{sex}^{235}$

232. E. Ellis, European Community Sex Equality Law (Oxford: Clarendon Press, 1991) at 38-9. The wording of Article 119 is based on ILO Convention No. 100, although Article 119 uses the phrase "equal work." while the ILO Convention uses the phrase "work of equal value" (at 41 ).

23.. Supra, note 232 at 5. Article 189 of the EEC Treaty provides that "A directive shall be binding, as to the result to be achieved, upon each Member State to which it is addressed, but shall leave to the national authorities the choice of form and methods."

2.3. EEC Council Directive 75/117 Council Directive of 10th Feb. 1975 on the Approximation of the Law's of the Member States Relating to the Application of the Principle of Equal Pay for Men and Women, OJ 1975 L45/19 /hereinafter Equal Pay Directivel. 
The Equal Pay Directive Article 2 obligated Member States to enact legislation enabling employees to pursue equal value claims in the courts. ${ }^{236}$ The Directive extended equal value claims beyond the public sector to the private sector, as Article 4 required that Member States take measures to ensure that provisions in individual contracts of employment, collective agreements, and wage scales that are contrary to the principle of equal pay be declared null and void or be amended. ${ }^{237}$ Accordingly, as in Ontario, in the United Kingdom, the principle of equal value claims extends to both the public and the private sectors. ${ }^{33}$

\section{Case 61/81 Commission v. United Kingdom}

The United Kingdom has been bound to provide equal pay for equal work, including work of equal value, since the Equal Pay Directive was required to be implemented by February 10, 1976. Evidently the European Commission was of the view that this obligation had not been met, as it commenced proceedings against the U.K. in 1981 alleging that the U.K. was in breach of Article 119 of the EEC Treaty. In particular, it was alleged that the U.K. had not introduced legislation permitting employees to claim equal pay for work of equal value free of sex discrimination. ${ }^{239}$ The European Court of Justice decided the case against the United Kingdom, ${ }^{240}$ and accordingly, the U.K. passed amendments to the Equal Pay Act to try to give effect to its obligations which came into effect in 1984.241

\section{B. EQUAL VALUE CLAIMS FOLLOWING THE EQUAL PAY (AMENDMENT) REGULATIONS 1983}

\section{Purpose of the Amendment Regulations}

Unfortunately the procedure set out under the Amendment Regulations and in the rules of procedure for the Industrial Tribunals ${ }^{242}$ hearing the cases is extremely complex. At the time the House of Lords debated them,

...they were described by Lord Denning as 'beyond compare ... no ordinary lawyer would be able to understand them ... the industrial tribunal would have the greatest of difficulty and the court of Appeal would probably be divided in opinion. 243

Ihid. art. 2.

Ihid. art. 4.

For a discussion of this, see Case 43/75 Defrenne v. Société Anonyme Belge De Navigation Aérienne [Sabena], [1976] 2 C.M.L.R. 98 (E.C.J.) below.

Supra, note 23 at I.

Case 61/81 Commission v. United Kingdom, [1982] E.C.R. 2601.

Equal Pay (Amendment) Regulations 1983, SI 1983/1794 reg. I /hereinafter the Amendment Regulations|. It should be noted that Regulation 1 of the Amendment Regulations provided that they do not extend to Northern Ireland. Similar Regulations govern that jurisdiction: Equal Pay (Amendment) Regulations (Northern Ireland) 1984.

Industrial Tribunal (Rules of Procedure) (Equal Value Amendment) Regulations 1983, SI 1983.

Supra, note 23 at $\mathrm{I}$. 
Simply put, the Amendment Regulations are intended to permit a woman to pursue an equal value claim where her work is of equal value to that of a man in similar employment, or vice-versa.

Provision for an equality clause where a woman is employed on work of equal value to that of a man in the same employment is found in Section 1(2)(c) of the amended Equal Pay Act. This section states that by virtue of the equality clause deemed to be included in a contract of employment, if a woman establishes that she is employed on work of "equal value to that of a man in the same employment," she is prima facie entitled under s. 1(2)(c) to have the terms of her contract treated as modified to bring them into line with the terms of his contract. ${ }^{2+1}$

\section{Procedure for Pursuing Equal Value Claims}

Under the Amendment Regulations, claims for equal pay may be made on the basis of like work, equivalent work, and work of equal value. Claims are determined first by an Industrial Tribunal. Thereafter, the possibility exists for appeals on a point of law to the Employment Appeal Tribunal, ${ }^{245}$ the Court of Session, ${ }^{2+6}$ and then to the House of Lords. Throughout, there remains the possibility of making a reference to the European Court of Justice. ${ }^{247}$

In order to make an equal value claim, there are three main steps to be taken at the Industrial Tribunal stage. The first step is a preliminary hearing where the employer has the chance to present various challenges to the claim which, if successful, can prevent the claim being fully heard on the facts. ${ }^{248}$ At the preliminary hearing stage, the employer may argue that there are no reasonable grounds for the claim, and if successful, the tribunal must dismiss the claim at that stage. ${ }^{249}$ This test applies only to equal value claims and not to like work or equivalent work claims. ${ }^{250}$

Leverton v. Clwyd Coumty Council (1989), I.R.L.R. 28 at 30-3I (H.L.). The case does not stand for this principle, but deals with the comparison called for under $\mathrm{s}$. $\mathrm{l}(6)$ regarding terms and conditions of employment observed at two or more "establishments." It stands for the proposition that the purpose of s. 1(6) is to "... enable a woman to eliminate discriminatory differences between the terms of her contract and those of any male fellow employee doing like work, work rated as equivalent or work of equal value, whether he works at the same establishment as her or in another establishment where terms and conditions of employment common to both establishments are observed." I.T. Smith and Sir J. Wood, Industrial Law, 4th ed. (London: Butterworths, 1989) at 238.

2th. Appeals may be made in Scotland from the Employment Appeal Tribunal to the Court of Session. In England, appeals on a point of law may be made from the Employment Appeal Tribunal to the Court of Appeal. See E.A. Marshall, General Principles of Scots Law', 5th ed. (Edinburgh: W. Green, 1991) at 35-37 with respect to the Court of Session. See supra, note 245 at 264 with respect to the Court of Appeal. raised in the domestic context are referred by a court or tribunal of a Member State to the European Court of Justice: See "EC Law: Reaching the Parts UK Law Cannot Reach" 39 E.O.R. 19 at 29. Supra, note 23 at 3.

249. Equal Pay Act, 1970, s. 2A(1). 
The employer may also challenge an equal value claim at the preliminary hearing on the basis that a job evaluation study gives different values to the work done by the woman and her male comparator, ${ }^{2.51}$ and there are no reasonable grounds for deciding that the evaluation in the study was made on a system discriminating on the basis of sex. ${ }^{252}$ This means that an existing job evaluation study may bar the equal value claim if there are no reasonable grounds for concluding that it is based on a sex discriminatory system. ${ }^{253}$

Thirdly, the employer may challenge the equal value claim at the preliminary hearing stage on the basis that the work is not of equal value; however, in the event that it is, there is a possibility that the pay difference is due to a "material factor" which is not the difference of sex. ${ }^{254}$ If this defence succeeds, the claim is dismissed. ${ }^{255}$

If the woman succeeds in making it past the preliminary hearing stage, the next stage involves preparation and presentation of a report by an independent expert comparing the value of the work of the woman making the claim to her male comparator. The last stage at the level of the Industrial Tribunal is the main hearing at which time an employer's material factor defence may be heard, perhaps for the second time, the independent expert's report may be challenged, and the claim be determined. ${ }^{256}$

In making an equal value claim, the burden of proof of discrimination lies with the applicant. ${ }^{257}$ The burden of proof in making a material factor defence is on the employer. ${ }^{258}$

\section{No Reasonable Grounds}

One of the first difficulties a claimant may be faced with when making an equal value claim is the "no reasonable grounds" determination set out in s. $2 \mathrm{~A}(1)$ of the amended Equal Pay Act. This test only applies to equal value claims, and does not apply to other types of equal pay claims. ${ }^{2.59}$ If the Industrial Tribunal is "... satisfied that there are no

Equal Pay Act, 1970, s. 2A(2).

Supra, note 23 at 3.

Supra, note 23 at 6.

Supra, note 23 at 3. For example, see the discussion of Enderby v. Frenchay Health Authority [199]] I.R.L.R. 44 (E.A.T.) below.

"Equal Pay Law: Paradise for Lawyers - Hell for Women" 35 E.O.R. 30 at 31.

Supra, note 23 at 3.

Supra, note 245 at 85-6. It should be noted that there is a draft Directive pertaining to cases where sex discrimination is alleged which will modify the burden of proof if it is adopted: Draft Sex Discrimination (Evidence) Directive [1988] 3 C.M.L.R. 272. Art. 3(1). The burden of proof would shift to the employer once the complainant established a prima facie case of direct of indirect discrimination. See S. Prechal \& N. Burrows, European Community Law Relating to Gender Discrimination (Alderahot: Darımouth, 1990) at 298-9. There is also a draft Directive on part-time work which would ensure part-time workers the same rights as full-time employees. Draft Directive on Volumary Part-Time Work [1982\} 2 C.M.L.R. 133. The draft Directives are opposed by one Member State, namely the United Kingdom.

This principle was recently confirmed by the EAT in The Financial Times v. Byrne (No. 2) [1992] I.R.L.R. 163 (E.A.T.).

Supra, note 23 at 5 . 
reasonable grounds for determining that the work is of equal value ...,"260 then the tribunal may dismiss the claim without referring the matter to an independent expert. The result of this provision has been that tribunals have carried out their own assessment of the requirements of the claimant's and comparator's jobs, generally under the headings found in $\mathrm{s}$. 1(2)(c) of the Act: effort, skill, and decision. ${ }^{261}$ This filtering provision is controversial since arguably the power to strike out claims which are "scandalous, frivolous or vexatious" should suffice to deal with hopeless cases. ${ }^{262}$

\section{The Employer's Job Evaluation Study as a Bar to a Claim}

A related "no reasonable grounds" obstacle is found in s. 2A(2) of the amended Equal Pay Act. This section provides that the tribunal shall not consider an equal value complaint if the woman's work and her comparator's work have been given different values under a study evaluating the demands made on them $^{263}$ and there are "... no reasonable grounds for determining that the evaluation contained in the study was ... made on a system which discriminates on grounds of sex."264 In this way, an employer's job evaluation study may bar an equal value claim at a preliminary stage. ${ }^{265}$

The job evaluation must meet three criteria in order to establish a defence under $\mathbf{s}$. $2 \mathrm{~A}(2)(\mathrm{a})$ that the work of the woman and her comparator have been rated as having different worth. First, it must be shown that the job evaluation meets the criteria in $s$. 1(5) of the Act which require evaluation of demands in terms of effort, skill, and decision. ${ }^{266}$ The case law has established that this requires the evaluation to be analytical ${ }^{267}$ and that it has been accepted by the parties involved. Secondly, it must be proven that the job evaluation system is non-discriminatory. Thirdly, the evaluation must compare the jobs as they were performed at the date the proceedings were issued. If these conditions are met, the claim must be dismissed. If they are not met, the employer's job evaluation may still be considered as evidence in determining whether the work is of equal value. ${ }^{268}$

\section{The Material Factor Defence}

The material factor defence is found in Section 1(3) of the Equal Pay Act, as amended and provides that an equality clause shall not operate in relation to a variation between the woman's contract and the man's contract if the employer proves the variation is

Equal Pay Act (U.K.), 1970, c. 41, s. 2(A)(1).

"Equal Value Update" (1991), 38 E.O.R. 12 at 15.

Supra, note 23 at 5.

"Equal Pay Law: 'Paradise for Lawyers - Hell for Women'” (1991) 35 E.0.R. 30 at 31.

Equal Pay Act (U.K.), 1970, c. 41, s. 2A(2).

Supra, note 23 at 6.

"Equal Value Update" (1990) 32 E.0.R. 13 at 20.

See Bromley v. $H \& J$ Quick [1988] I.R.L.R. 249 (C.A.) regarding the requirements to succed in establishing a defense under s. 2A(2). As well, see Case 237/85 Rummler v. Dato-Druck Gmbh [1987] E.C.R. 2101 for clarification of the requirements for job classification systems stipulated in Article 1(2) of the Equal Pay Directive.

$2 n \times$.

Supra, note 266 at 20.
} 
genuinely due to a material factor that is not the difference of sex. ${ }^{269}$ Unfortunately, s. 1(3) does not explain what justification is required by the employer to show that the pay inequality is not due to sex discrimination but some other factor. ${ }^{270}$

The material factor defence is similar to the exceptions to pay equity permitted under the Ontario Pay Equity Act such as temporary skills shortages necessitating a higher rate of pay, or red circling, for example. ${ }^{271}$ There has been a great deal of litigation trying to delineate the scope of the material factor defence, since the nature of the justification required by the employer is to show that the pay inequality is not due to sex discrimination, but some other factor. ${ }^{272}$ This defence may be raised both at the time of the preliminary hearing, and at the stage of the main hearing after the Tribunal has made a finding of work of equal value. ${ }^{273}$

\section{Same Employment}

In making an equal pay claim, the claimant will fail unless he or she proves that the comparison is with a person of the opposite sex in the "same employment."274 Section 1(6) of the Equal Pay Act provides that two employers will be treated as associated if one is a company of which the other has control either directly or indirectly or if a third person has control of both of them. As well, men are to be treated as being in the same "employment" as a woman if they are,

...employed by her employer or any associated employer at the same establishment or establishments in Great Britain which include that onc and at which common terms and conditions of employment are observed cither generally or for employees of the relevant classes. ${ }^{275}$

\section{Independent Expert}

If the employer's defences of no reasonable grounds, no reasonable grounds due to a job evaluation study, and the material factor defence fail at the preliminary stage, then the Tribunal must order an independent expert's report to compare the value of the claimant's work and her comparator's. Section $2 \mathrm{~A}(\mathrm{l})(\mathrm{b})$ stipulates that the Tribunal may not determine a question of equal value until it has received the independent expert's report. ${ }^{276}$ Once the report is submitted to the Tribunal, the Tribunal must decide whether to accept the report and admit it in evidence, whether it agrees with the expert's

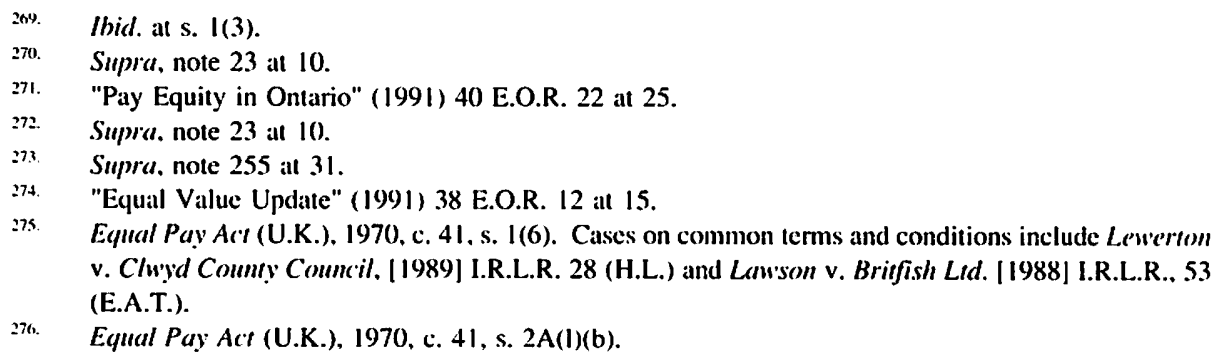


conclusion on equal value, and finally will consider any remaining genuine material factor defences of the employer. ${ }^{277}$

The Tribunal may refuse to admit the expert's report on the grounds that the expert has not taken into account all relevant information supplied and representations made, or that the expert's conclusion is one which could not reasonably have been reached, or that for some other material reason it is unsatisfactory. If the report is not admitted, the Tribunal must order another expert's report. ${ }^{278}$

Once the independent expert's report is admitted in evidence it will carry considerable weight, however, the Tribunal is not required to give it any greater weight than reports commissioned by the partics. ${ }^{279}$

\section{Administration and Enforcement}

The Sex Discrimination Act, 1975 stipulates that the Equal Opportunitics Commission has the statutory duty to investigate, lay complaints, and promote equality ${ }^{280}$ with respect to the Equal Pay Act and the Sex Discrimination Act. Section 53 of the Sex Discrimination Act provides that the Commission has the duty to work towards the elimination of discrimination, to promote equality of opportunity; and to keep under review the working of the Equal Pay Act and the Sex Discrimination Act. ${ }^{2 \times 1}$ The E.O.C. must draw up proposals for amending the Acts when it thinks it necessary or when it is so required by the Secretary of State.

The E.O.C. has various enforcement powers under the Sex Discrimination Act. First, the E.O.C. may conduct formal investigations into possible violations, which may ultimately lead to issuance of a non-discrimination notice requiring the person named not to commit unlawful discriminatory acts. Secondly, the E.O.C. may bring proceedings in an Industrial Tribunal with a view to making an application for an injunction restraining persistent discrimination. ${ }^{2 \times 2}$ Thirdly, the E.O.C. may apply for an injunction to restrain a person who is guilty of persistent discrimination from committing further discrimination. ${ }^{28.3}$ Fourthly, s.75 authorizes the E.O.C. to give assistance, including advice and legal representation to complainants where the case raises an issue of principle,

\footnotetext{
277. "Equal Value Update" (1991) 38 E.O.R. 12 at 27.

27x. Ihid.

23\%. Supra, note 22 at 132-33.

2xal. Supra, note 22 at 132-33.

$2 \times 1$.

Halshury's Law's of England, 4th ed., Vol. 16 (London: Butterworths, 1976) at 546-47, para. $771: 22$. Sex Discrimination ACt (U.K.). 1975, c. 65. 229.57 and 73(1). See: Equal Oppormunities Commission, Legislating for Change? Review of the Sex Discrimination Legislation (Manchester: EOC, 1986) at 25. The Commission carried out ten formal investigations in its first ten years. Sec Equal Opportunities Commission. United Kingdom Report under the UN Comvention on the Elimimation of All Forms of Discrimination Against Women: Vions of the Equal Opportunities Commission (Manchester: EOC, 1987) at 13.
}

2xi. The E.O.C. may also initiate procededings under ss. 72 and 73 of the Sex Discrimination Act alleging contravention of the Act's prohibitions on instructing and pressuring others to discriminate and regarding unlawful discriminatory advertisements, which will not be discussed here. 
or if it would be unreasonable to expect the individual to deal with the case unaided because of the complexity of the matter, or if any other special consideration applies. ${ }^{284}$ At present, the E.O.C. does not have a general power to bring legal proceedings in its own name when it believes that an unlawful discriminatory practice or act exists. ${ }^{285}$ In addition to the statutory powers listed above, the E.O.C. may seek judicial review regarding any infringement of public law rights in respect of the legislation. ${ }^{286}$

\section{CASE LAW ON EQUAL VALUE CLAIMS}

This area of the law is vast and complex. Accordingly, it is neither possible nor desirable to thoroughly review the body of case law which exists in Britain regarding equal value claims. However, it is important to understand how the courts have interpreted the legislation in view of Community law. It is the interplay of Community law and British law, together with the complexity of the provisions and procedure, that make this area of the law a challenge.

This section will explain several concepts which are fundamental to understanding this area, including the direct effect of Treaty Articles and Directives; vertical and horizontal effect and as well the distinction between direct and indirect sexual discrimination.

\section{Direct Effect of European Community Law}

In order to join the European Community, the U.K. passed the European Communities Act 1972, ${ }^{2 \times 7}$ which gave the force of law to the three European Community Treaties in the U.K., as well as to secondary legislation provided in accordance with the treaties without further enactment. ${ }^{28 x}$

Community law is made up inter alia of various types of legislative acts, some of which are 'directly effective.' In this context, the term refers to provisions of Community law that are capable of application by national courts at the suit of individuals. ${ }^{289}$ The case law in the European Court of Justice has developed the concepts of vertical direct effect and horizontal direct effect. Vertical direct effect refers to rights of individuals

2x4. The power to give assistance to complainants has been used extensively by the E.O.C. to determine the construction and scope of the Equal Pay Act and the Sex Discrimination Act. For example, the E.O.C. gave assistance under s. 75 for formal applications in twenty-three cases involving equal value claims during 1990. See Equal Opportunitics Commission, Annual Report 1990 (Manchester: E.O.C., 1991) at 35 .

2xs. The E.O.C. would like to have this general power as it would be cost effective for it to seek to eliminate a discriminatory practice as opposed to various individuals conducting litigation regarding the same issue. See: Equal Opportunities Commission, Equal Treatment for Men and Women: Strengthening the Acts (Manchester: E.O.C., 1988) at 18-19. Equal Opportunities Commission, Legislating for Change?, supra, note 282 at 25. See the discussion of R. v. Secretary of State for Employment ex parte Equal Opportunities Commission. [199|] I.R.L.R. 493 (Q.B.) below.

European Communities Act (U.K.), 1972, c. 68.

Ibid. at s. 2(1).

J. Steiner, Textbook on EEC Law, 2d ed. (London: Blackstone Press, 1990) at 20-1. 
under Community law which are exercisable directly against the State. Horizontal direct effect refers to individuals invoking Community law rights against other individuals. ${ }^{290}$

\section{(a) Defrenne (No. 2): Direct Effect of Article 119 of the EEC Treaty}

The question of the direct effect of Article 119 of the EEC Treaty was decided by the European Court of Justice in Defienne (No. 2). ${ }^{291}$ Briefly, the facts were that a Belgian air line hostess brought a claim against her employer regarding compensation for loss suffered in terms of salary, allowance on termination, and pension as a result of the fact that male cabin stewards performing identical work did not receive equal pay. ${ }^{292}$

Various questions were referred to the Court pursuant to Article 177 of the EEC Treaty, including whether Article 119 was directly effective. The Court placed the Article in the context of the Treaty, noting that the purpose of the Article was to avoid the situation where undertakings in states that have implemented equal pay suffer a competitive disadvantage within the Community compared with undertakings in states that have not yet eliminated discrimination against female workers regarding pay. ${ }^{29.3}$ As well, the Court observed that Article 119 was enacted as part of the social objectives of the Community and is meant to ensure social progress and improved living and working conditions. ${ }^{.94}$ The Court concluded that "... the principle of equal pay forms part of the foundations of the Community...."295 Accordingly, the Court refused to consider arguments based on the resistance of certain Member States to implementation of this principle. ${ }^{2 \%}$

The Court made the distinction between direct and indirect discrimination, stating that direct discrimination may be identified solely with the aid of the criteria in Article 119 based on equal work and equal pay. The types of direct discrimination that may be identified solely on the basis of Article 119 criteria include those that have their origin in legislative provisions or collective agreements and which may be detected on the basis of a purely legal analysis.

This is particularly the case where men and women receive different pay for equal work in the same establishment or service, whether public or private. In such a case, Article 119 is directly effective and gives rise to individual rights the courts are required to protect. ${ }^{297}$

\footnotetext{
Supra, note 289 at 23.

291. Case 43/75 Defrenne v. Sociésé Anonyme Belge De Navigation Aérienne (Sabena), [ 1976] 2 C.M.L.R. 98 (E.C.J.) [hereinafter Defreme (No.2)].

292. Ihid. at 102.

293. Supra, note 291. Obviously an analogous argument regarding the desirability of avoiding competitive disadvantage can be made with respect to the Ontario pay equity legislation in the context of the Canada-U.S. Frec Trade Agreement, or any future Canada-U.S.-Mexico Free Trade Agreement. Ihid. at 122.

Ihid. at 123.

lhid. at 123-24.

Ihid. at 123-24.
} 
The Court stated that indirect discrimination can only be identified by reference to more explicit implementing provisions at the Community or Member State level. Article 119 is also aimed at eliminating this type of discrimination. ${ }^{298}$

The European Court of Justice held that because Article 119 is mandatory, the prohibition on discrimination between men and women applies not only to actions by public authorities, but also to collective agreements and contracts between individuals. ${ }^{299}$

Thus, Article 119 may be relied on before national courts and national courts are obligated to ensure protection of the rights Article 119 vests in individuals, particularly regarding discrimination arising directly from legislative provisions or collective labour agreements; as well as where men and women receive unequal pay for equal work performed in the same establishment, whether private or public. ${ }^{3 \times 0}$ The case also established the principle that where discrimination in pay is to be remedied, the pay of the successful claimant is to be "levelled up" to that of the comparator. ${ }^{301}$

\section{(b) Effect of the Equal Pay Directive}

As has been seen, the Defrenne (No. 2) decision ${ }^{302}$ established that Article 119 can have both vertical and horizontal direct effect. In other words, it can bind employers in the public and private sectors.

In the past directives were considered not to be directly effective. However, there has been a trend in the Community case law towards holding directives to be directly effective vertically, ${ }^{303}$ although not horizontally. ${ }^{3 / 4}$ However, in effect the Equal Pay Directive

lhid. The Defremme (No.2) decision is remarkable because it is the only instance where the European Court of Justice has held unequivocally that an Article of the EEC Treaty apparently addressed to Member States has horizontal direct effect, and the ECJ adopted a prospective ruling for the first lime.

Ibid. at 123.

Ihid. at 123. See "EC Law: Reaching the Parts U.K. Law Cannot Reach" (1991) 39 E.O.R. 19 at 22.

Case 43/75 Defienne v. Société Anonyme Belge De Navigation Aérienne /Sabena], [1976] 2 C.M.L.R. 98 (E.C.J.).

Sec for example Case $41 / 74$ Van Duyn v. Home Office, [1974] E.C.R. 1337 wherein a directive was held to be directively effective vertically because the provision set down an obligation that was not subject to any exception or condition and which did not require intervention by either Community institutions or Member States. See L. Collins, European Community Law in the United Kingdom. 4th ed. (London: Butterworths, 1990) at 83.

The European Court of Justice denied the horizontal effect of a Directive in Case 152/84 Marshall v. Southampton \& South-West Hampshire Area Health Authority (Teaching), [1986] E.C.R. 723 on the basis that Article 189 of the EEC Treaty obligates Member States to implement directives and accordingly directives in themselves may not impose obligations on individuals, and provisions in directives may not be relied on against individuals. See Collins, supra, note 303 at 88-89. Directives are still of significance in the private sector due to the principle of "indirect effect" which means that national legislation enacted to implement directives must be interpreted by domestic courts in light of the directives. See "EC Law: Reaching the Parts U.K. Law Cannot Reach" (1991) 39 E.O.R. 19 at 29, particularly the discussion of Case C-106/89 Marleasing v. la Commercial Internacional de 
has both vertical and horizontal direct effect since it has been held simply to elucidate the material scope of Article 119 of the EEC Treaty and is not the source of new rights or obligations. ${ }^{315}$ The European Court of Justice has made it clear that Article 119 "equal work" is to be interpreted as including work of equal valuc. The court stated in Worringham and Humphreys v. Lloyds Bank ${ }^{316}$ that the objective of Directive 75/117 was to facilitate the implementation of Article 119, and that the reference to work of equal value in Article 1 of the Directive refers by implication to the concept of pay in Article 119. In any case, since the Directive merely elucidates Article 119, its provisions may be invoked both horizontally and vertically in an Article 119 claim. ${ }^{317}$

The fact that Article 119 may be relied on in equal value claims was confirmed by the European Court of Justice in Murphy v. Bord Telecom Eiream, ${ }^{30 x}$ a case referred to it by the High Court of Ireland. In this case, the ECJ held that Article 119 covers unequal value claims (where the claimant's work was assessed at a higher value than that of her comparator) as well as equal value claims. The court also stated that to the extent that the disparity in pay was due to sex discrimination, Article 119 may be relied on by employees in actions before national courts and tribunals. The national courts are required to give domestic law an interpretation according with Community law requirements and to hold domestic law inapplicable to an extent this is not possible. ${ }^{3(4)}$

\section{Equal Value Claims Alleging Direct Sex Discrimination}

\section{(a) Hayw'ard v. Cammell Laird Shiphuilders Lid.}

Two cases in which equal value claims were made following the amendments to the Equal Pay Act introduced by Parliament after the decision in Commission v. United Kingdom ${ }^{311}$ are significant. The first case in which an equal value claim was made in the United Kingdom was Hayu'ard v. Cammell Laird Shiphuilders Lid."

Alimentacion. [1990] E.C.R. 1-4135 therein. It appears that the Court of Appeal in England has not been impressed by the decision in Marleasing. which arguably instructs the House of Lords that it has a duty to construe national legislation to achieve the goals of directives, even if Parliament has done nothing to give effect to the Community law obligation in national latw. See the decision in W(b) v. EMO Air Cargo (U.K.) Ltd. [1992] I.R.L.R. 116 (C.A.).

Supra, note 232 at $97-98$.

Case 69/80 Worringham and Humpheress v. Llovds Bank. [1981] E.C.R. 767, at para. 21. See: A. Arnull, The General Principles of EEC Law and the Individeal (London: Leicester University Press. 1990) at 217. This principle was reiterated in Case 96/80 Jenkins v. Kingsgate (Clothing Productions) Lid.. [1981] E.C.R. 911 and other more recent cases.

J. Steiner. Texthook on EFC Law. 2nd ed. (London: Blackstone Press. 1990) at 236.

Case 157/86 Murphy v. Bord Telecom Eireumn. |1988| E.C.R. 686.

This is the complex issue of the primacy of Community law, details of which are beyond the scope of this anticle. For full discussion. see J. Usher. European Community Law and National Law: The Irreversible Transfer?' (London: Allen \& Unwin, 1981).

Sipra, note 240.

Hayward v. Cammell Laird Shipbuilders Lid. (1988). I.C.R. 464. (1988) I.R.L.R. 257 (H.L.). 
Briefly, in this case a cook made an equal value claim in which she selected a painter, a joiner and an insulation engineer as her male comparators. ${ }^{312}$ The issue was whether the terms of her contract as a whole should be considered when deciding whether any term or condition of her contract was less favourable than that of her comparator, or just the specific term or condition complained of. ${ }^{313}$ The employer based its defence in part on the argument that she should not receive a pay award if her contract as a whole, including such items as sickness benefits, was favourable compared with those of the men. ${ }^{314}$

Ms. Hayward was unsuccessful in the Industrial Tribunal, the EAT, and the Court of Appeal. The House of Lords held that the Equal Pay Act permitted comparison between each term in a contract. Ms. Hayward was entitled to redress regarding her basic pay, the term in her contract that was less favourable than her comparators. ${ }^{315}$ The approach taken by the House of Lords in the decision is likely correct, ${ }^{316}$ since the European Court of Justice recently held in Barber v. Guardian Royal Exchange Group that "... the principle of equal pay must be ensured in respect of each element of remuneration and not only on the basis of a comprehensive assessment of the consideration paid to workers." ${ }^{.317}$

This case is of interest because it contrasts with the position taken under the Pay Equity Act, 1987 in Ontario. In that Act, "pay" is defined to include both pay and benefits. A value is attributed to benefits and added to pay when calculating job rates. If the female job class has benefits with greater value than the male job class used as the appropriate comparator, it is thus possible that the female job rate will equal the male job rate and no pay equity adjustment will be required. ${ }^{318}$

\section{(b) Pickstone}

The second important equal value case is the House of Lords decision in Pickstone, ${ }^{319}$ wherein various female warehouse operatives brought an equal value claim comparing their work with a male checker warehouse operative. The issue was whether a woman doing "like work" compared with one man, but which is also of equal value with the work

\footnotetext{
31. An entire book has been devoted to comparing this case to one on comparable worth in the United Slales: supra, note 227.

313. H. Carty, "The Peaks and Troughs of the Equal Value claim: A Progress Report" (1990) J.S.W.L. 394 at $\mathbf{3 9 6 .}$

314. Ihid. at 395.

315. Supra, note 311 at 259-60. There is obiter dicta in the decision that the employer's argument regarding other terms in the contract being more favourable might be raised as a genuine material factor defense under s. I(3) of the Act to justify the different terms provided that there is no direct or indirect discrimination embedded in the two pay structures of the woman and her male comparator The recent case of Byrne v. The Financial Times Ltd. (1991), I.R.L.R. 417 (E.A.T.) also considers the material factor defense and whether the components of Pay should be compared in equal value claims.

316. "Equal Value Update" (1990) 32 E.O.R. 13 at 25.

317. Ibid. Case C-262/88 Barber v. Guardian Royal Exchange Group) (1990) I.R.L.R. 240 (E.C.J.).

31x. "Pay Equity in Ontario" (1991) 40 E.O.R. 22 at 24.

31. Pickstone v. Freemans plc [1988] I.R.L.R. 357 (H.L.).
} 
of another man, may claim equal pay with the other man when she already receives the same pay as the man doing like work. The employer argued that a woman is barred from an equal value claim until it is shown that there are no men engaged in like work or equivalent work under the Equal Pay Act s. 1(2)(a) and (b). ${ }^{320}$

The House of Lords chose to interpret Regulations amending the Equal Pay Act against their literal meaning in order to achieve a result compatible with Community law in this case. ${ }^{321}$ It was held that the equal value claim provisions in s. 1(2)(c) were introduced into the Equal Pay Act in order to comply with the European Court of Justice decision in Case 61/81 Commission v. United Kingdom. The provisions were construed so as to be consistent with the Community obligation since Parliament had passed Regulations specifically to give effect to Community law.

The Court stated that under Article 119 of the EEC Treaty, the right to make an equal value claim is not dependent upon there being no man employed on like work or equivalent work. ${ }^{322}$ The Court held that the woman would only be barred from pursuing an equal value claim where her chosen comparator was employed in like work or equivalent work. ${ }^{323}$

This case is of fundamental importance because it illustrated the House of Lord's approach to equal value claims where domestic law provisions conflict with Community law and showed a willingness to read U.K. law in such a manner as to make it consistent with the Community obligation. ${ }^{324}$

\section{Indirect Discrimination}

Equal value claims on the basis of indirect sex discrimination in pay may be brought under the Equal Pay Act, as amended, as well as under Community law. There are two fundamental cases on indirect sex discrimination in pay which have been applied in a consistent line of cases. Although Bilka-Kaufhaus v. Weber von Hartz and Rainey v. Greater Glasgow' Health Board are not equal value cases, the principles enunciated in them apply equally to equal value claims. They establish the defence of "objective justification" in equal pay claims, and economic factors as a material defence.

Ibid. at 220-21.

Supra, note 289 at $40-41$.

Supra, note 319 at 363 .

Supra, note 313 at 397.

However, altention should be drawn to the House of Lords decision in Dake v. Reliance. [1988] 1 C.M.L.R. 719 (H.L.) wherein the Court refused to construe the Sex Discrimination Act. 1975 in a manner which would give effect to the Community obligation since Parliament had not passed the amending Sex Discrimination Act. 1986 at the relevant time and the amending $A c t$ did not have retrospective effect. Accordingly, no remedy was available where there was no Parliamentary activity. The decision in Duke v. Reliance was recently reaffinmed by the English Court of Appeal in Webh v. EMO Air Cargo (U.K.) Lud., [1992] I.R.L.R. 116 (C.A.). 
(a) Bilka-Kaufhaus v. Weber Von Hartz: Objective Justification

Bilka-Kaufhaus v. Weber von Hart: ${ }^{325}$ is a fundamental case wherein the European Court of Justice established principles interpreting Article 119, indicating what constitutes justification for indirect sex discrimination in pay under Community law. ${ }^{326}$ Briefly, the facts were that an employer in the Federal Republic of Germany paid retirement pensions to full-time employees; whereas part-time employees were only eligible for such pensions if they had worked for the company for at least 20 years, including 15 years full-time employment. ${ }^{327}$

At issue was whether indirect discrimination infringing Article 119 of the EEC Treaty existed where an employer employing predominantly women excludes part-time employees from benefits under its pension scheme although the exclusion affects disproportionately more women than men. There were other issues, including whether the disadvantage can be justified on the basis that the objective of the policy was to employ as few part-time workers as possible. ${ }^{32 x}$

The Court held that if it were established in this case that a considerably smaller percentage of women than men worked full-time, that the exclusion of part-time workers from the pension scheme would violate Article 119 of the Treaty if considering the problems women have in trying to arrange matters in order to work full-time, the measure cannot be explained by factors excluding sex discrimination. ${ }^{329}$ If the enterprise can prove that its pay practice can be explained by "... objectively justified factors unrelated to any discrimination on grounds of sex ..., ${ }^{.330}$ then there would not be a violation of Article 119.

The Court found that the adoption of a pay policy excluding part-time workers from its pension scheme, regardless of sex, could be justified by the employer arguing that it seeks to limit the number of this type of employees if it is found that the means selected to achieve this objective "... correspond to a real need on the part of the undertaking, are appropriate with a view to achieving the objective in question and are necessary to that end." ${ }^{.331}$

If the national court determines that these three criteria are met, the fact that the measures affect far more women than men does not suffice to conclude that there is a

3.4.

iis

Case 170/84 Bilka-Kaufhuns v. Weher von Harz, [1986] E.C.R.1607 |hereinafter Bilka-Kaufhaus). Supra, note 229 at 807.

Supra. note 325 at 1621.

Ibid. at 1622-23 and 1626-27. The European Court of Justice applied the principles from the Court's judgement in Case 96/80 Jenkins v. Kingsgate (Clothing Productions) Lid., [1981] E.C.R. 911 to these facts, since the practice in Bilka of granting occupational pensions only to full-time employees is comparable to the practice in. Jenkins of fixing a lower hourly rate of pay for part-time work than for full-time work.

Ihid. at 1627.

Ibid.

Ibid. at 1631. 
breach of Article 119.3.32 This is the test of "objective justification" in indirect sex discrimination. It is up to the national court to determine whether the grounds advanced by the employer to justify a pay practice that applies irrespective of sex, but which in fact affects more women than men. "... may be regarded as objectively justified economic grounds. ${ }^{.333}$

(b) Interpretation of Bilka in Great Britain: Rainey v. Greater Glasgow Health Board

The Bilka test of objective justification in indirect discrimination cases was first considered in Britain in Rainey v. Greater Glasgow Health Board. ${ }^{3.4}$ In this case, a prosthetist employed by the National Health Service brought a "like work" claim under the Equal Pay Act on the basis that her salary was lower than that of an earlier male recruit. Her comparator had been recruited from private practice where salaries were higher in order to establish a prosthetic fitting service. After the initial recruitment. employees hired later were placed on a lower scale, whether they were male or female. ${ }^{335}$

The issue was whether the policy decision to offer private prosthetists the option of entering the NHS at their existing salaries could constitutc a material difference other than the difference of sex between the two cases, thus constituting a defence under s. 1(3) of the Act. ${ }^{336}$ The NHS contended that its policy was created to ensure that enough qualified prosthetists from the private sector would enter the service. ${ }^{337}$

Lord Keith of Kinkel stated that in a situation such as this where there is no issue of intentional direct or indirect sex discrimination, "... a difference which is connected with economic factors affecting the efficient carrying on of the employer's business or other activity may well be relevant. ${ }^{1338}$

The court reviewed the European Court of Justice decisions in Jenkin. ${ }^{339}$ and BilkaKanfhaus $^{3+1}$ and concluded that in these cases the ECJ had established that the meaning and effect of Article 119 "... would not exclude objectively justified grounds which are other than economic, such as administrative efficiency in a concern not engaged in commerce or business. ${ }^{3+11}$

33. Ibid.

3i1. Ibid. at 1628 .

in. Rainey v. Greater Glasgow Ilealh Board, (1987) 2 C.M.L.R. II (H.L.).

335. Ibid. at $11-13$.

3.3. Ibid. at 15.

337. M. Weiner, "Fundamental Misconceptions About Fundamental Rights: The Changing Nature of Women's Rights in the EEC and their Application in the United Kingdom" 31:2 (1990) H.I.L.J. 565 at 591 .

33x. Supra, note 334 at 17.

33. Case 96/80 Jenkins v. Kingsgate (Clothing Productions) Lal., |1981| E.C.R. 911.

.40. Case 170/84 Bilka Kaufhaus Gmbh v. Weber von Hartz. |1986| E.C.R. 1607.

34. Supra, note 334 at 20. 
The House of Lords held that there is no reason to construe s. 1(3) of the Equal Pay Act as conferring greater rights on workers than Article 119 and accordingly "...a relevant difference for purposes of s. 1(3) may relate to circumstances other than the personal qualifications or merits of the male and female workers who are the subject of comparison. ${ }^{1342}$ Accordingly, Ms. Rainey's appeal failed since the grounds put forth by the employer were capable of constituting a material factor defence. ${ }^{343}$

This decision has been criticised on the basis that its effect could be that employers may gain efficiency at the expense of the female employees which the legislation was designed to protect. However, since it does not appear that Bilka disallows this type of justification, the decision is likely correctly decided in terms of Community law. ${ }^{3.44}$

\section{(c) R. v. Secretary of State for Employment Ex Parte Equal Opportunities Commission}

The issue of the locus standi of the E.O.C. to seek judicial review of a decision by the Secretary of State declining to accept the E.O.C.'s contention that the U.K. is in breach of its Community law obligations was considered in $R$. v. Secretary of State for Employment ex parte Equal Opportunities Commission. ${ }^{3.5}$

In this indirect sex discrimination case, the E.O.C. took the position that the qualifying conditions for unfair dismissal and redundancy payments for part-time workers under the Employment Protection (Consolidation) Act 1978 are discriminatory. Since the provisions provide far less favourable treatment for part-time workers than full-time workers, and $90 \%$ of part-time workers in the U.K. are women, the effect of the legislation is discriminatory and conflicts with U.K. obligations under Community law. The E.O.C. sought judicial review of the Secretary of State's decision declining to accept that the U.K. is in breach of its Community obligations in relation to the less favourable treatment of part-time workers regarding the right not to be unfairly dismissed, the right to compensation for unfair dismissal, and in relation to the method of calculating their statutory redundancy pay.

The Court of Queen's Bench held that the E.O.C. had a sufficient interest to have locus standi. If the employment arrangements for a large number of part-time employees operate in a way that creates improper discrimination and the Secretary of State wrongly decides not to take steps to extinguish such wrongful discrimination, an issue of public law is raised in which the E.O.C. has a sufficient interest to bring judicial review proceedings. ${ }^{366}$ It was not necessary for U.K. women to wait for the European Commission to proceed against the U.K. in the European Court of Justice. ${ }^{347}$

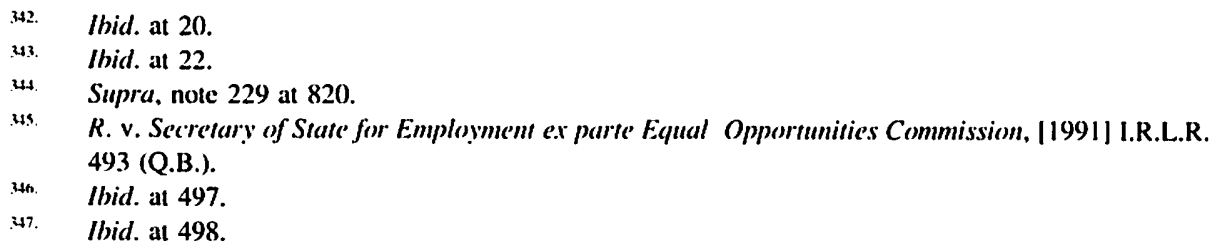


The Court held that "pay" includes redundancy payments due to the Barher ${ }^{348}$ decision and held that payments of compensation for unfair dismissal also fall within the scope of Article 119 and the Equal Pay Directive. With regard to the main issue, namely whether the 1978 Act is lawful in requiring part-time workers to complete five years of employment before qualifying for a redundancy payment, the court of Queen's Bench held that Article 119 of the EEC Treaty and the Directives had not been infringed. It held that the Secretary of State had objectively justified the scheme, including the method of calculating redundancy payments, despite evidence that more women than men were affected by changes from full-time to part-time employment. ${ }^{349}$ The case has now gone to the Court of Appeal.

\section{(d) Enderby v. Frenchay Health Authority and Secretary of State for Health}

The case of Enderby v. Frenchay Health Authority ${ }^{350}$ is a significant Employment Appeal Tribunal case dealing with the material factor defence and indirect pay discrimination. The case was recently referred to the European Court of Justice by the Court of Appeal ${ }^{351}$ and raises issues of fundamental importance.

This was a test case supported by the Equal Opportunities Commission in which the appellant argued that the European Law on unintentional indirect discrimination has been misinterpreted by U.K. courts. ${ }^{352}$ The case is of interest for comparative purposes with the Pay Equity Act provisions regarding permissable differences in pay once pay equity is achieved which are due to differences in bargaining strength.

\section{(i) The Industrial Tribunal Level}

Briefly, Mrs. Clarke and Dr. Enderby, who were two senior speech therapists employed by the National Health Service, claimed they were employed on work of equal value with a male pharmacist and a clinical psychologist whose salary exceeded theirs by about $60 \%{ }^{353}$ Dr. Enderby requested that her claim for equal pay be referred to an independent expert so that a report comparing her work and her comparator's could be prepared. At the Industrial Tribunal, the speech therapists based their arguments on both direct and indirect discrimination, and failed on both counts.

The Industrial Tribunal held that the relevant collective bargaining process did not have sexual discrimination embedded within it with regard to speech therapists, and the differences in pay related to such matters as qualifications, hours, type of work, and responsibility. ${ }^{344}$ Thus, the difference in pay was due to genuine material factors

Barher v. Guardian Royal Exchange Group. |1990| I.R.L.R. 240 (E.C.J.).

Ihid. att 505.

Enderby v. Frenchay Health Authority and Secresary of State for Health [1991| I.R.L.R. 44 (E.A.T.) [hereinafter Enderby v. Frenchay Health Authorityl.

Enderby v. Frenchay Health Authority and Secretary of State for Health. [1992] I.R.L.R. 15 (C.A.).

Supra, note 350 at 47.

Supra, note 350 .

Supra, note 350 at 50. 
to sex, even if the women's work was of equal value to their comparators. The main material factor identified at the Tribunal level was the existence of different collective bargaining arrangements for the groups, and it was not accepted that these arrangements were tainted by sexual discrimination. ${ }^{35 s}$

Mrs. Clarke did not appeal. Dr. Enderby did not appeal against the finding that there was no direct discrimination in the wage setting process, but appealed on the basis of unintentional indirect discrimination on the basis of sex in relation to pay. The employer cross appealed against the tribunal's failure to hold that the pay difference was due to market forces and was permissible under s. 1(3) of the Equal Pay Act. ${ }^{356}$

\section{(ii) The Appellant Speech Therapist's Argument}

The appellant speech therapist's argument in the E.A.T. was that a prima facie case of unintentional indirect discrimination based on gender is established where a woman is doing work of equal value with her comparator, and where she is paid less than her comparator and is a member of a group that is predominantly female, while her comparator is a member of a group which is predominantly male. The difference in pay is a "pay practice." ${ }^{357}$ It is this difference in pay which must be justified by an employer. Accordingly, a collective agreement cannot justify a pay difference, even if it is untainted by gender.

The appellant further argued that it was not necessary to show a requirement or condition which must be satisfied by the woman before she can achieve cqual pay, since the claim was made under the Equal Pay Act read with Community law so that the principles in s. I(1)(b) of the Sex Discrimination Act were irrelevant. ${ }^{358}$

It was submitted that Section 1(3) of the Equal Pay Act, the material factor defence clause, is irrelevant because it is not part of Community law, and conflicts with it. Arguably, the only defence open to a respondent based on the Bilka-Kaufhaus case is objective justification. In the alternative, it was argued that if a condition is required, in this case it would be that Dr. Enderby would need to change her profession to that of her comparator in order to earn the higher pay. ${ }^{359}$

\section{(iii) The Respondent Employer's Argument}

The respondent employers contended that prior to establishing a prima facie case of unintentional indirect discrimination requiring justification, that the pay practice must be analyzed and the term or condition identified which the woman must satisfy before she

iss. "Pay Practice' cannot be indirect discrimination" (1991) I.R.S. Ind. R.L.I.B. 420 (8 March 1991) at 12.

3\$ "No Indirect Discriminattion Against Speech Therapists" 36 E.O.R. 29 at 29.

(s). Stupra, note 350 at 51 .

15x. Ibid. s. $1(1)($ b) of the Sex Discrimination Act, 1975 requires an applicant to show that a requirement or condition had been applied to her when seeking to establish indirect discrimination. See supra, note 355. 
can achieve equal pay. It must be shown that because she is a woman that she will be unable to comply with it or will be less able to than a man in a similar position. It is this condition which must be satisfied on Bilka principles. The employer argued that collective bargaining and the collective agreement may provide justification for the whole of the difference so long as they are not tainted by gender. ${ }^{3(x)}$

On appeal to the Employment Appeal Tribunal the employer argued that the difference in pay of the pharmacists was due to market forces ${ }^{361}$ and that the Industrial Tribunal had erred in rejecting this defence by holding that it did not justify the whole of the pay difference. $^{362}$

\section{(iv) Judgment of the Employment Appeal Tribunal}

The Employment Appeal Tribunal dismissed the appeal and allowed the cross-appeal. Wood, J. observed that the appellant speech therapists had argued that it is the pay practice which they defined as the difference in pay which must be justified. The EAT rejected this on the basis that the pay practice is instead a system that brings about a difference in pay either by establishing a rule that is consistently followed or through a contractual term. He rejected the submission that the result of the pay difference constitutes the system or practice. ${ }^{363}$

The EAT stated that the language of s. 1(3), which provides the material factor defence. is of "cause" not "result." "36t Wood, J. stated that the object of the U.K. and Community statutory provisions "... is not a general wage fixing or elimination of wage differences or to insist that every job should be the subject of a job analysis...." ${ }^{365}$

The Tribunal took the view that the legislation was not intended to disrupt the established negotiating machinery which was untainted by gender in this case. The EAT stated that if the appellants' submission regarding collective bargaining were well-founded, then in each case where a trade union represents a woman in negotiations, it could be liable if it did not carry out a job analysis. The Tribunal noted that this could be expensive and the employer might not agree with the analysis. The Tribunal observed that the only difference it had been able to discern between the U.K. and the Community was in procedure, and not substantive principles. The U.K. procedure is desirable because of the expense of expert evidence, and the disruption to the business affairs of the employer and to the negotiations of trade unions while the issue of equal value is decided. Under U.K. procedure, the "... test of causation and whether it needs justification may be examined upon the assumption that the work is of equal value and before the issuc of equal value is itself decided....".36t

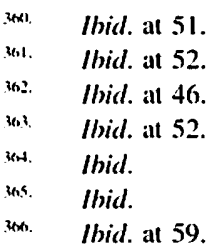


The Tribunal rejected the primary submission and held that it was necessary to identify a "factor" which is neutral on its face that causes the disparate impact when establishing a prima facie case of unintentional indirect discrimination. If this factor is not gender tainted, no justification for it is necessary. It must be justified, however, if it is gender tainted in that the woman is able to bring herself within the provisions of $s .1(1)(b)(i)$ and (iii) of the 1975 Act. In this casc, no causative factor had been shown.

It was held that collective bargaining and collective agreements are relevant to justification, and if there is no gender tainting, they can explain and justify a difference in pay. ${ }^{367}$ As well, the EAT ruled that once it has been proven that "market forces" are genuinely material, this justifies the whole of any pay difference. In Wood, J.'s view, it would be virtually impossible to determine what part of the wage paid is attributable to market forces. ${ }^{368}$

The EAT rejected the speech therapist's alternative submission which was that the condition in this case was that Dr. Enderby would have to become a pharmacist to obtain the higher rate of pay, stating that this was a "mere truism."369 It concluded that Dr. Enderby's pay difference was due to her being differently qualified than her comparator, rather than being due to her being a woman. ${ }^{370}$

\section{(v) The Court of Appeal}

On appeal, the Court of Appeal stated that the main issue in this case is whether the employer has two lines of defence in satisfying s. 1(3) of the Echual Pay Act or one. If there are two lines of defence, the employer would be able to state that there was no discrimination because he did not seek to apply any condition or requirement for female employees to meet, and even if there was such a condition, it was justified in the circumstances. There is only one line of defence if Dr. Enderby is correct. On this view, once it is proven that in practice a woman in a predominantly female profession receives less pay or benefits than male comparators doing work of equal value, the employer must prove that the disparity is justified. ${ }^{371}$

The Court of Appeal held that the issue whether it is necessary to justify the whole of the variation in pay in making a material factor defence or whether it is sufficient to justify only a part required a reference to the European Court of Justice. In the meantime, the Court of Appeal held that the Industrial Tribunal had incorrectly applied a less stringent test of objective justification for the variation in pay than that set out in Bilka. A further hearing must be held to consider the grounds for variation in accordance with the Bilka test after the ECJ answers the questions in the reference. ${ }^{372}$

iis

31

37

Ibid. all 62.

"No Indirect Pay Discrimination Against Speceh Therapists" (1991) 36 E.O.R. 29 at 30. Stupra. note 350 at 60 .

Ibid.

Enderby v. Frenchay Health Authority, [1992] I.R.L.R. I5 at 20 (C.A.).

Ibid. all 22-23. 
The questions in the Reference ask for guidance regarding whether Article 119 requires employers to objectively justify a pay difference between sex-segregated work of equal value where the pay determination process does not discriminate on the basis of sex; whether different collective bargaining processes can justify the difference in pay; and whether labour shortages may be used to objectively justify the pay difference. ${ }^{373}$

\section{(vi) Concern Regarding the Judgment}

The EAT has been criticised extensively for this decision. First of all, for the assumption made in the case that U.K. principles on indirect discrimination law are applicable in interpreting Article 119 of the EEC Treaty. ${ }^{374}$ Secondly, the EAT decision has been criticised for concluding that in a case of indirect discrimination that some "factor" must be identified as the cause of the claimants' lower pay. The implication in the case that this "factor" does not require justification unless it is itself tainted by gender is contrary to the definition of indirect discrimination which assumes that the condition will be gender neutral. Arguably, it is instead the effect of the condition which may give rise to indirect discrimination. ${ }^{375}$ Thirdly, the decision has been criticised for ruling that collective bargaining and a collective agreement are relevant to justification and can explain a difference in pay. This is because the onus is on the employer to prove that the difference in pay is "objectively justified" by reference to business needs. Arguably, collective bargaining is a subjective process and the right to equal pay for work of equal value should not be bargained away. ${ }^{376}$

The decision is also noteworthy in that the EAT held that a genuine material factor defence must be identified, and if necessary, justified in accordance with s. 1(1)(b) of the Sex Discrimination Act, 1975. This is significant as it was previously thought that it would be possible that Tribunals would accept the existence of the material factor in itself as sufficient to defeat an equal pay claim. ${ }^{377}$

Finally, concern has been expressed with respect to the conclusion that once market forces are proved as a material factor defence, that the whole of the pay difference is justified. This is because of a concern that market forces will be used as a defence and enable employers to circumvent the ordinary requirements of proof. ${ }^{37 x}$

The Court of Appeal decision is notable in that it confirmed that the employer must provide objective justification for a pay difference where work is of equal value by proving that the difference is appropriate and necessary under the Bilka-Kaufhaus test. ${ }^{371}$

\footnotetext{
M. Rubenstein. "Highlights: January 1992" [1992] I.R.L.R. I at 2.

A. Korn, "Employment Law Update" 132:23 Solicitors J. 699 at 700.

"Pay Practice' cannot be indirect discrimination" (1991) IRS Industrial Relations Legal Information Bulletin 420 (8 March 1991 ) at 13.

Siıpra, note 368 at 32.

Supra, note 355.

Supra, note 368 at 32 .

M. Rubenstein. "Highlights: January. 1992" [1992] I.R.L.R. I at 2.
} 
Obviously the principles to be established in the reference to the European Court of Justice are of fundamental importance to equal value law.

\section{CRITICISMS OF BRITISH EQUAL VALUE LEGISLATION AND SUGGESTED AMENDMENTS}

There are many aspects of British equal value legislation that can be criticized. The Equal Opportunities Commission, which is the body charged with investigating complaints regarding violations of the Equal Pay Act and the Sex Discrimination Act, 1975,380 published formal proposals to amend the Acts in 1990. The Commission's legal adviser has stated that the laws cause confusion and years of delay. ${ }^{381}$ In its report, the E.0.C. stated that:

In our view the present legislation is ineffective for dealing with pay inequalities deeply rooted. often unconsciously. in pay structures and collective agreements and is arguably an inadequate discharge by the U.K. of its obligations under the Equal Pay Directive..$^{3.2}$

The Commission noted that since the Amendment Regulations were passed, that on average under 20 claims were decided from 1984 - 1989. The average time period for a claim to go through the equal value procedure is seventeen months. The claims are expensive to bring and Legal Aid is unavailable for representation at industrial tribunals, although legal advice may be sought prior to the tribunal hearing. The cost and complexity of claims has meant that claimants who lack representation by the E.O.C. or a trade union are at a disadvantage. ${ }^{3.3}$

The E.O.C. made 29 recommendations for amendments to the legislation. The commission proposes that a single act be passed which would combine the areas covered by the Equal Pay Act and the Sex Discrimination Act with the requirements of EEC law. The Commission is critical of the existing distinction that is made between the contractual aspects of the employment relationship which are governed by the Equal Pay Act and the non-contractual aspects which are governed by the Sex Discrimination Act. ${ }^{384}$

The other major proposals of the Commission include the suggestion that the material factor defence should only be permitted after a finding of equal value has been made, legislation should require that employees in the same employment as a successful applicant doing similar work should be entitled to the same award, the employer's job evaluation study should not bar an equal value claim, and abolition of the requirement that a tribunal determine whether there are no reasonable grounds for an equal value claim. ${ }^{385}$

Supra, note 228.

B. Clement, "Equal Pay Laws are 'A Hell for Women'" The Independent (16 Nov. 1990) 4. Sitpra. note 23 at 2.

Silpra, note 23 at 2.

Supra. note 23 at 19.

Supra. note 23 at 24-25. 
There are additional criticisms which may be made regarding the British legislation. Those who are of the view that equal value claims should be extended to predominantly female sectors where women are employed in low paid jobs,express concern that the equal value claim depends upon locating a male comparator. ${ }^{386}$ This is similar to the concerns in Ontario which led to the introduction of Bill 168 to add proportional value comparisons and proxy comparisons for the predominantly female sectors.

As well, concern has been expressed that job evaluation to redress sex discrimination in pay is gender biased, due to the perception that women's work is "unskilled." ${ }^{387}$ This is a concern when the existence of a job evaluation study commissioned by the employer currently may act as a bar to an equal value claim.

It seems highly unlikely that a new unified act will be passed addressing the concerns which have been expressed unless there is a change in government. The Conservative government rejected the proposals of the Equal Opportunities Commission to introduce new legislation on women's employment rights, on the basis that voluntarism is preferable. The vice chairman of the ministerial group on women's issues has stated that the Government must weigh the cost to business and the damage to economic competitiveness through new rules, against greater protection of employees. ${ }^{38 x}$

This was an issue during the recent national election campaign as both the Liberal Democrats and the Labour party indicated that they favour introduction of new equal pay and sex discrimination legislation. ${ }^{3 \times 4}$ The Labour Party also proposes the introduction of minimum wage legislation in Great Britain which has been a controversial issue. ${ }^{3(*)}$ However. since the Conservative party again formed the Government after obtaining a majority in the April, 1992 general election, ${ }^{391}$ it does not seem probable that any amendments to strengthen or improve the legislation will be made.

\section{COMPARISON OF PAY EQUITY LEGISLATION IN ONTARIO TO EQUAL VALUE LEGISLATION IN GREAT BRITAIN}

As we have seen, the legislatures in Ontario and Great Britain have taken the policy decision to enact legislation giving effect to the principle of equal pay for work of equal value, free of sex discrimination. The Ontario Pay Equity Act states expressly in s. 4 that the purpose of the Act is to redress systemic gender discrimination in compensation for work performed by female job classes. Accordingly, since the assumption is made that sex discrimination in determining remuneration is embedded in the system, the legislation benefits women, and men only benefit to the extent they are in female job classes which

\footnotetext{
3x6. L. Drummond, "What is Law Doing for Women?" (1991) 175 Scolag 58 at 58.

3x7. P. Kahn, "Unequal Opportunities: Women. Employment and the Law" in S. Edwards, ed.. Gender. Sex and the Law' (London: Croom Helm, 1985) 79 at 93.

txx. B. Clement, "Bottomley Rules out New Laws on Women's Rights" The Independent (4 Dec. 1991) 5.

3x). B. Clement, "Labour Attacked for Tokenism" of Equality Plans" The Independent (3 March 1992) 4.

340. P. Hosking, "Waging War on Minimum Pay" The Independent on Sunday (2 February 1992) 6.

591. R. Oakley, "Major Plans Reshuffle Today" The Times (11 April 1992) 1.
} 
receive pay adjustments. It is peculiar that a policy decision was taken to enact equal value legislation in this way, since the possibility also exists for gender discrimination to occur against men in determining pay, including benefits. ${ }^{392}$

In contrast, the legislation governing equal value claims in Great Britain provides that both male and female employees are entitled to an equality clause securing equal pay for work of equal value, without sex discrimination. ${ }^{303}$ In the writer's opinion, the British and Community law provisions are better than the Ontario legislation in that protection against sex discrimination in determining remuneration is extended to both sexes. The coverage of the legislation in both jurisdictions is similar, however, in that the Pay Equity $A c t$ and Article 119 of the EEC Treaty and the Equal Pay Act, 1970 all require equal pay for work of equal value, free of sex discrimination, in both the public (or state) and private sectors.

With respect to the method of enforcement, the Pay Equity Act is unique among equal value jurisdictions in that it requires employers in the public and private sector to achieve pay equity. The burden is on the employer to implement pay equity plans and to make pay equity adjustments until pay equity is achieved. In contrast, the legislation governing equal value claims in Great Britain is "complaint-based" and the burden is on the individual to prove equal value. ${ }^{304}$

Comparisons are made under the Pay Equity Act between male and female job classes. This means that positions with similar duties, responsibilities, qualifications, recruiting procedures, and compensation schedules are combined into a job class for purposes of evaluating the job classes by a gender neutral comparison system. Pay equity adjustments are then to be implemented for female job classes as necessary to achieve pay equity.

In contrast, the legislation in Great Britain operates at the level of the individual claimant, who chooses a comparator whose work he or she thinks is of equal value to their own work. ${ }^{395}$ Any pay award achieved by the claimant is not required to be extended by the employer to employees in the same establishment performing similar work. ${ }^{3 \%}$ From the perspective of extending the benefits of awards and settlements to other employees performing similar work, the legislation in Ontario is better than that in Great Britain.

Provision is made in the legislation in both Ontario and in Great Britain for employers to conduct job evaluations. In Ontario, public sector employers and private sector employers with 100 or more employees are required to evaluate job classes using a gender neutral comparison system. They are then required to prepare and post pay equity plans. Private sector employers with between 10 and 99 employees have the choice of following

For example, see The Europein Court of Justice decision in Casc C-262/88 Barber v. Guardian Royal Exchange Group [1990] I.R.L.R. 240 (E.C.J.).

Equal Pay Act (U.K.), 1970, c. 41, s. 1(1).

"Pay Equity in Ontario" (1991) 40 E.O.R. 22 at 22.

Supra, note 22 at 133.

Supra, note 23 at 14. 
this procedure, or using instead systematic compensation practices to achieve pay equity by the mandatory adjustment date. ${ }^{397}$

In contrast, the legislation in Great Britain does not require employers to create an analytical job evaluation system that is free of sex discrimination, although it may be wise to implement one in order to create a bar to equal value claims. ${ }^{308}$ Provision is made for job evaluation since an independent expert's report comparing the value of the claimant's work and the comparator's work is required before a tribunal may rule on whether the two positions are of equal value. Such a comparison does not generally value the jobs throughout the entire establishment, but is limited to several positions which are at issue. ${ }^{3 \%}$ Employers may introduce their analytical job evaluation systems in evidence, but are not required to create such systems under the legislation.

The definition in Ontario regarding what constitutes an "establishment" in s. 1(1) of the Pay Equity Act and the definition of the "same employment" in s. 1(6) of the Equal $P a y A c t$ are similar in that they both rest on a definition of employer which involves the concepts of ownership and control. Bill 168 would amend the Pay Equity Act so that pay equity plans are assumed by new owners when businesses are sold.

The definition of "pay" includes pay as well as benefits under the Pay Equity Act. Each individual benefit has a value attributed to it, if possible, which is added to pay to form the job rate. Accordingly, where a female job class has benefits of higher value than a male job class, it is possible that no pay equity adjustment will be necessary for the female job class. This would occur where, taken as a whole, the pay and benefits of the female job class are at least equal to the male job class job rate.

In contrast, in Great Britain the decision in Hayward v. Cammell Laird ${ }^{(1(x)}$ established that pay and benefits are not to be considered as a whole when determining whether the remuneration of a claimant is not less favourable than her comparator's. The House of Lords rejected the argument that an employer is not obligated to pay a woman employed on work of equal value the same basic pay as her comparator when her remuneration is not less favourable when considered as a whole. ${ }^{+11}$

The legislation is the same in both jurisdictions in that it is forbidden to lower wages to comply with the duty to pay equally for work of equal value, free of sex discrimination. ${ }^{402}$ Obviously, this is desirable from the perspective of an employee making a claim. As well, the legislation in both jurisdictions is comparable in that each permits exceptions to the requirement of equal pay for work of equal value. In Ontario, the permissible exceptions include such matters as skills shortages causing a temporary inflation in compensation, red circling, a gender neutral seniority system, and merit

\footnotetext{
397. Supra. note 46 App. at 113-14.

rox. "Paly Equity in Ontario" 40 E.O.R. 22 at 22-23.

sws. Supra, note 23 at 6-8.

4(w). Hayward v. Cammell Laird (1988), I.R.L.R. 257 (H.L.).

4ir. "Pay Equity in Ontario" (1991) 40 E.O.R. 22 at 24.

4h. See Defreme (No. 2), above and the Pay Exluity Act, S.O. 1987. c. 34, s. 9(1).
} 
compensation plans. Further, once pay equity is achieved, s. 8(2) permits differences in compensation between a female job class and a male job class if the employer proves the difference is due to different bargaining strength.

These exceptions permitting disparities in pay between comparable male and female job classes are similar to those permitted in Great Britain under the material factor defence. However, Enderby v. Frenchay Health Authority ${ }^{403}$ raises the question of the extent to which collective bargaining may constitute a material difference. In particular it is not yet known whether a genuine material factor relied on, such as market forces, must justify the entire pay disparity to succeed as a defence to an equal value claim. ${ }^{4(4)}$

The legislation in both jurisdictions is complex. The Ontario legislation will become even more so in the event that Bill 168 is passed and proportional value comparisons and proxy comparisons are included in the Act. The legislation in Britain is extraordinarily complex, partly because it involves the application of European Community law. It is also complex because of the provisions set out in the Equal Pay Act and Amendment Regulations, particularly the elaborate system of defences available to employers in equal value claims.

\section{CONCLUSION}

The legislatures in Ontario and Great Britain have made the commitment to the principle of equal pay for work of equal value, free of sex discrimination. This necessitates changing traditional pay structures in order to achieve this goal. The British legislation is less interventionist in that the onus is on the employee to initiate a claim. In contrast, the Ontario legislation places the onus on public sector employers and private sector employers with 10 or more employees to achieve pay equity. Private sector employers with between 10 and 99 employees have an option whether to post pay equity plans, but those who choose not to post plans with between 50 and 99 employees must achieve pay equity by January 1,1993 and those with between 10 and 49 employees must achieve pay equity by January 1, 1994. Private sector employers with 100 or more employees and public sector employers must prepare and post pay equity plans.

The legislation in both jurisdictions is complex. The procedures required to achieve equal pay for work of equal value, free of gender discrimination involve considerable time and expense. For example, the obligation to create pay equity plans and use gender neutral comparison systems in Ontario involves considerable use of resources in terms of time, since the traditional criteria used in evaluating work must necessarily be questioned to ensure there is no sex discrimination. The elaborate system of defences in Great Britain and the provision for appeals through many levels of courts means that a claimant must be extremely tenacious to receive an equal value award. The appeal system may cause great expense on the part of employers, employees, and the state. 
There is an obvious response to the criticism that the legislation is costly in terms of money and time. The tribunal in Webster v. Hoover plc. considered an employer's argument that the need to avoid damaging repercussive claims made indirect discrimination justifiable, and rejected the submission, saying:

\footnotetext{
...The tribunal is very well aware of the fact that any award of equal pay is likely to start off a repercussive claim and that these repercussive claims can be potentially very damaging to an employer. Nevertheless it seems to this tribunal that it would be outrageous if an employer were to be allowed to continue to act in a sexually discriminatory way simply in order to avoid distuption in his pay system.....115
}

The tribunal went on to state that employers can avoid such a situation by instituting a properly agreed non-sexually discriminatory job evaluation scheme.

Finally, the statistics reveal that the gender wage gap in both Ontario and Great Britain is gradually decreasing over time, so that by 1989 women's carnings were approximately $67.6 \%$ of men's in both jurisdictions when the British gross weekly earnings figures were used. The extent to which this is due to equal pay and equal value legislation is difficult to assess. There is no doubt that the legislation is affecting the way that work is evaluated and compensated in these jurisdictions, and from that perspective, their proponents can certainly claim success. It remains to be seen whether the legislation in Ontario and Great Britain succeeds in completely eradicating the portion of the wage gap which is due to sex discrimination. 